\title{
fśmb \\ FEDERATION OF \\ STATE MEDICAL BOARDS
}

\section{U.S. States and Territories Modifying Requirements for Telehealth in Response to COVID-19 (Out-of-state physicians; preexisting provider-patient relationships; audio-only requirements; etc.)}

\section{Last Updated: April 12, 2023}

\begin{tabular}{|c|}
\hline States with Waivers: 3 \\
\hline States with Waivers, not allowing new applications: 1 \\
\hline States without Waivers (or closed waivers): 46 + DC \\
\hline States with long-term or permanent interstate telemedicine: $21+$ GU + CNMI + PR + USVI \\
\hline
\end{tabular}

On April 10, 2023, President Biden signed a resolution formally ending the coronavirus national emergency that began in March 2020. However, the COVID Public Health Emergency (PHE), will continue until May 11, 2023, as was previously announced by the administration.

\section{State}

Alabama

\section{Note}

- The Medical Licensure Commission of Alabama hereby finds that the need for qualified physicians to provide medical services in Alabama warrants the emergency adoption of this rule to provide for the issuance of an emergency license to physicians licensed in other states who may assist with this health emergency. The intent of this rule is to provide for the expedited issuance of medical licenses to qualified physicians who desire to provide health care to citizens of Alabama suffering from and affected by the 2019 novel coronavirus known as COVID-19. The Medical Licensure Commission hereby finds that physicians who obtain an emergency certificate of qualification by endorsement from the State Board of Medical Examiners are eligible for an emergency medical license... An emergency license issued under this rule shall expire 120 days after the effective date of this rule, or when the Governor of Alabama proclaims the termination of the state's public health emergency, whichever is sooner. An emergency license shall not be renewed. Applicants for an emergency license shall not be required to pay a fee.

- Re: Alabama Medicaid - The extension of telemedicine services is effective March 16, 2020. This extension allows clinicians to provide medically necessary services that can be appropriately delivered via telecommunication services including telephone consultations.. These actions will be effective for one month, expiring on dates of service April 16, 2020. It will be reevaluated for a continuance as needed.

- Re: controlled substances - If you have a current DEA registration in any jurisdiction, upon issuance of the Temporary Emergency Medical License, you will receive an Alabama Controlled Substances Certificate for the sole purpose of treating patients suffering from and affected by COVID-19. The Alabama Controlled Substances Certificate will specifically prohibit the prescribing of controlled substances via telemedicine.

- $[6 / 8 / 21$ Update] - It is not the case that a physician may practice telemedicine in any state as long as there is a license in at least one other state. To practice telemedicine in Alabama, the physician must hold one of the Alabama medical licenses that are available (Alabama full traditional license, a license via the Interstate Medical Licensure Compact, or special purpose license to practice medicine across state lines).

- Re:Special purpose [interstate] license-However, the Alabama Board of Medical Examiners does issue a license "limited solely to the practice of medicine-or osteopathy-across-state lines via telecommunications. These licensees are not authorized to provide in-person treatment in Alabama."

- [5/18/22 Update] re: Special purpose licenses abolished - On Apr. 12, 2022, Governor Kay Ivey signed Act No. 2022-302 effectively abolishing the SPL which allowed the practice of medicine and osteopathy across state lines via telemedicine. No new SPL applications will be accepted after May 26, 2022. Currently active Special Purpose licenses will remain active until their natural expiration date. No Special Purpose licenses will be renewed.

- Physicians desiring to continue to practice telemedicine in Alabama will be required to
Citation

ALBME Emergency

Rule Statement

ALBME Telemedicine Guidance

Initial Emergency License Instructions

Temporary License Application

Guidance re: $\mathrm{AL}$ Medicaid 


\begin{tabular}{|c|c|c|}
\hline & $\begin{array}{l}\text { obtain a full license or a license through the Interstate Medical Licensure Compact. } \\
\text { (ALBME Guidance). } \\
\text { - }[7 / 12 / 22 \text { Update] re: infrequent interstate telemedicine - However, as part of that } \\
\text { legislation, there is an exception for physicians "who provide [telemedicine] services on } \\
\text { an irregular or infrequent basis (defined as fewer than } 10 \text { days or } 10 \text { patients per } \\
\text { calendar year), or when the services are provided in consultation with a physician } \\
\text { licensed in the state. The bill also explicitly allows a physician-patient relationship to be } \\
\text { established without an in-person exam, and prescribing can include controlled } \\
\text { substances under certain circumstances. } \\
\text { - Status - Inactive, waivers currently rescinded - On July 20, 2020, the Board and Commission } \\
\text { extended the expiration of existing and new emergency licenses to November 17, 2020. All } \\
\text { temporary emergency licensees that wish to continue practicing in Alabama after November } \\
\text { 17, 2020, should apply now for permanent licensure through the Board (typically 2-3 } \\
\text { months) or the Interstate Medical Licensure Compact (within } 30 \text { days). It is anticipated that } \\
\text { licenses should be issued within } 48 \text { hours of receipt of application. }\end{array}$ & \\
\hline Alaska & 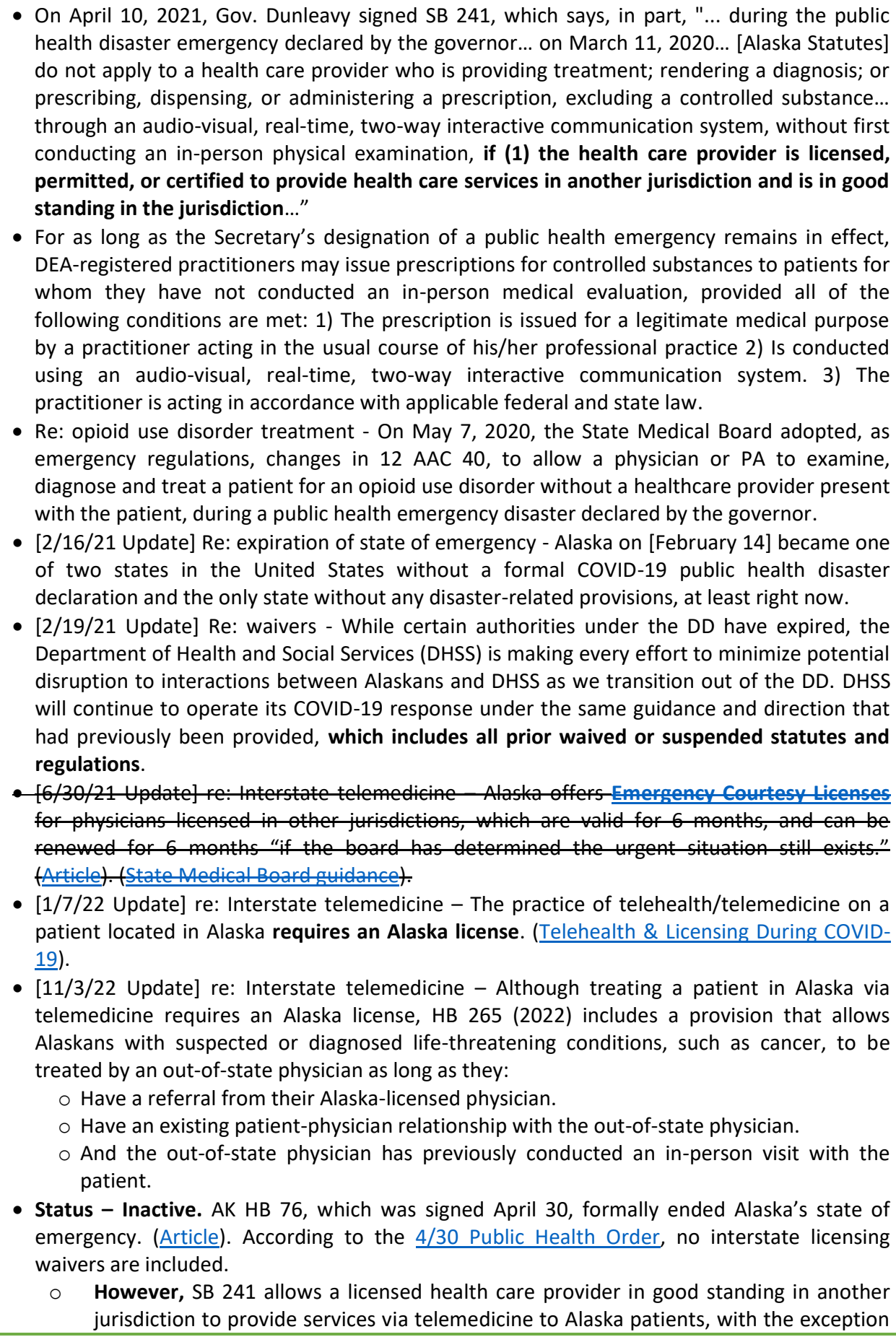 & $\begin{array}{l}\frac{\text { Courtesy License }}{\underline{\text { Application }}} \\
\frac{\text { Emergency }}{\underline{\text { Regulation }}} \\
\frac{\text { Telehealth \& }}{\text { Licensing During }} \\
\underline{\text { COVID-19 }} \\
\underline{\text { Bulletin 20-07 re: }}\end{array}$ \\
\hline
\end{tabular}




\begin{tabular}{|c|c|c|}
\hline & $\begin{array}{l}\text { of prescribing controlled substances (see above) during a declared state of } \\
\text { emergency. }\end{array}$ & \\
\hline Arizona & $\begin{array}{l}\text { - [MDs]: The Arizona Medical Board (AMB) announces the following available temporary } \\
\text { emergency licenses for Physicians (MDs) to practice in Arizona and the extension of the time } \\
\text { frame for renewal of MD licenses during the COVID-19 State of Emergency: MDs licensed in } \\
\text { another state are eligible to apply for temporary licensure in the State of Arizona using the } \\
\text { emergency temporary licensure application... All MD temporary emergency licenses expire } \\
\text { after } 90 \text { days, or at the time the State of Emergency is declared to be over whichever shall } \\
\text { occur first. } \\
\text { - [DOs]: In accordance with Arizona Revised Code, individuals can apply for a temporary } \\
\text { license with the Board to aid in the diagnosis and treatment of COVID-19 in Arizona. } \\
\text { - Re: Telemedicine coverage - Gov. Ducey [on March } 25,2020 \text { ] issued an Executive Order [EO } \\
\text { 2020-15] requiring health care insurance companies to expand telemedicine coverage for all } \\
\text { services that would normally be covered for an in-person visit... It remains in effect until the } \\
\text { termination of the declared public health emergency... Includes all electronic means of } \\
\text { delivering telehealth including telephone and video calls; Ensures that a patient's home is } \\
\text { considered an approved location to receive telemedicine services; ... And prohibits a } \\
\text { regulatory board from requiring a medical professional who is authorized to write } \\
\text { prescriptions to conduct an in-person examination of a patient prior to the issuance of a } \\
\text { prescription. } \\
\text { - [5/5/21 Update] - Re: interstate telemedicine - On June } 5,2021, \text { AZ HB } 2454 \text { was signed, } \\
\text { which permanently allows health care providers licensed in another jurisdiction, in good } \\
\text { standing and not subject to current or past disciplinary actions; to practice telemedicine } \\
\text { with Arizona patients. Licensees must register with the act in compliance with Arizona laws } \\
\text { including scope of practice and liability insurance, among others. The venue for any violation } \\
\text { is that of the resident. } \\
\text { Status - Inactive, on May } 5, \text { Gov. Ducey issued EO } 2021-13 \text {, rescinding prior telemedicine- } \\
\text { related executive orders, and referencing the comprehensive HB } 2454 \text {. However, Arizona } \\
\text { offers interstate telemedicine via Registration system, see above. }\end{array}$ & $\begin{array}{l}\frac{\text { AZ DHS Guidance }}{\text { EO 2020-15 }} \\
\frac{\text { Press Release re: }}{\frac{\text { Telemedicine }}{\underline{\text { Coverage }}}} \\
\frac{\text { EO 2020-07 }}{\text { AZ HB 2454 }} \\
\frac{\text { Temporary MD }}{\underline{\text { License }}} \\
\frac{\text { Temporary DO }}{\text { License }} \\
\frac{\text { Status of AHCCCS }}{\text { Emergency Authority }} \\
\frac{\text { Requests }}{\text { State Resource Page }} \\
\frac{\text { Universal License }}{\text { Application }}\end{array}$ \\
\hline Arkansas & 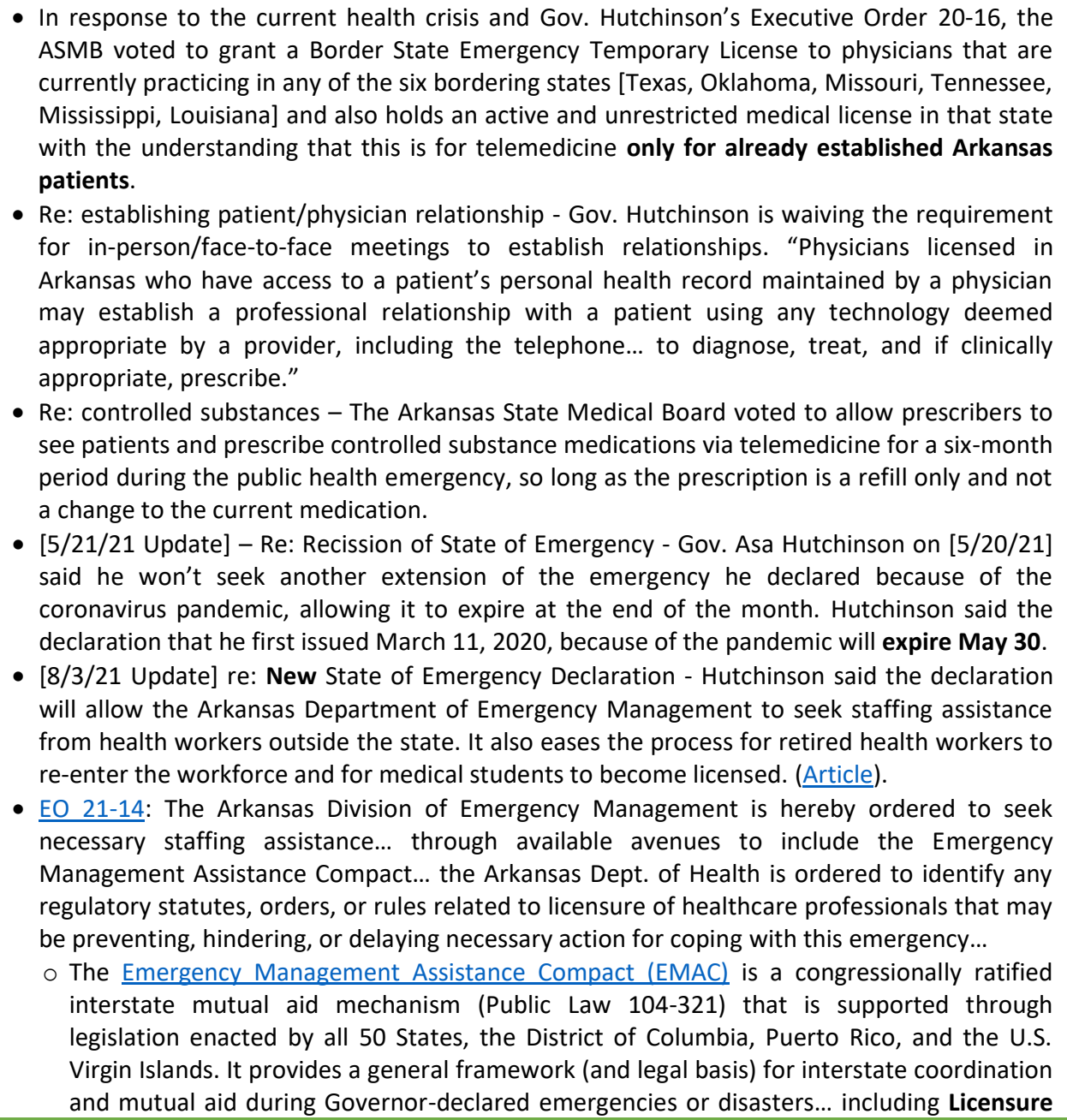 & $\begin{array}{l}\frac{\text { Border State }}{\text { Emergency License }} \\
\frac{\text { Instructions \& }}{\underline{\text { Application }}} \\
\frac{\text { Executive Order 20- }}{\underline{16}}\end{array}$ \\
\hline
\end{tabular}




\begin{tabular}{|c|c|c|}
\hline & $\begin{array}{l}\text { and permit waivers for medical and other professionals } \\
\text { - }[9 / 29 / 21 \text { Update] re: Emergency declaration recission - Arkansas Gov. Asa Hutchinson on } \\
\text { [9/28/21] said he'd allowed the state's public health emergency for the coronavirus } \\
\text { pandemic to end, saying he didn't need any additional powers to respond to it. (Article). } \\
\text { - }[1 / 7 / 22 \text { Update] re: interstate telemedicine - Healthcare providers must be fully licensed or } \\
\text { certified in Arkansas to provide services in the state unless the out-of-state provider is only } \\
\text { providing episodic consultation services. (AR Code } 17-80-404(d) \text { ). } \\
\text { - Status - Inactive, the state's emergency declaration expired September 27, } 2021 \text { (see } \\
\text { above). }\end{array}$ & $\underline{\text { State Resource Page }}$ \\
\hline California & 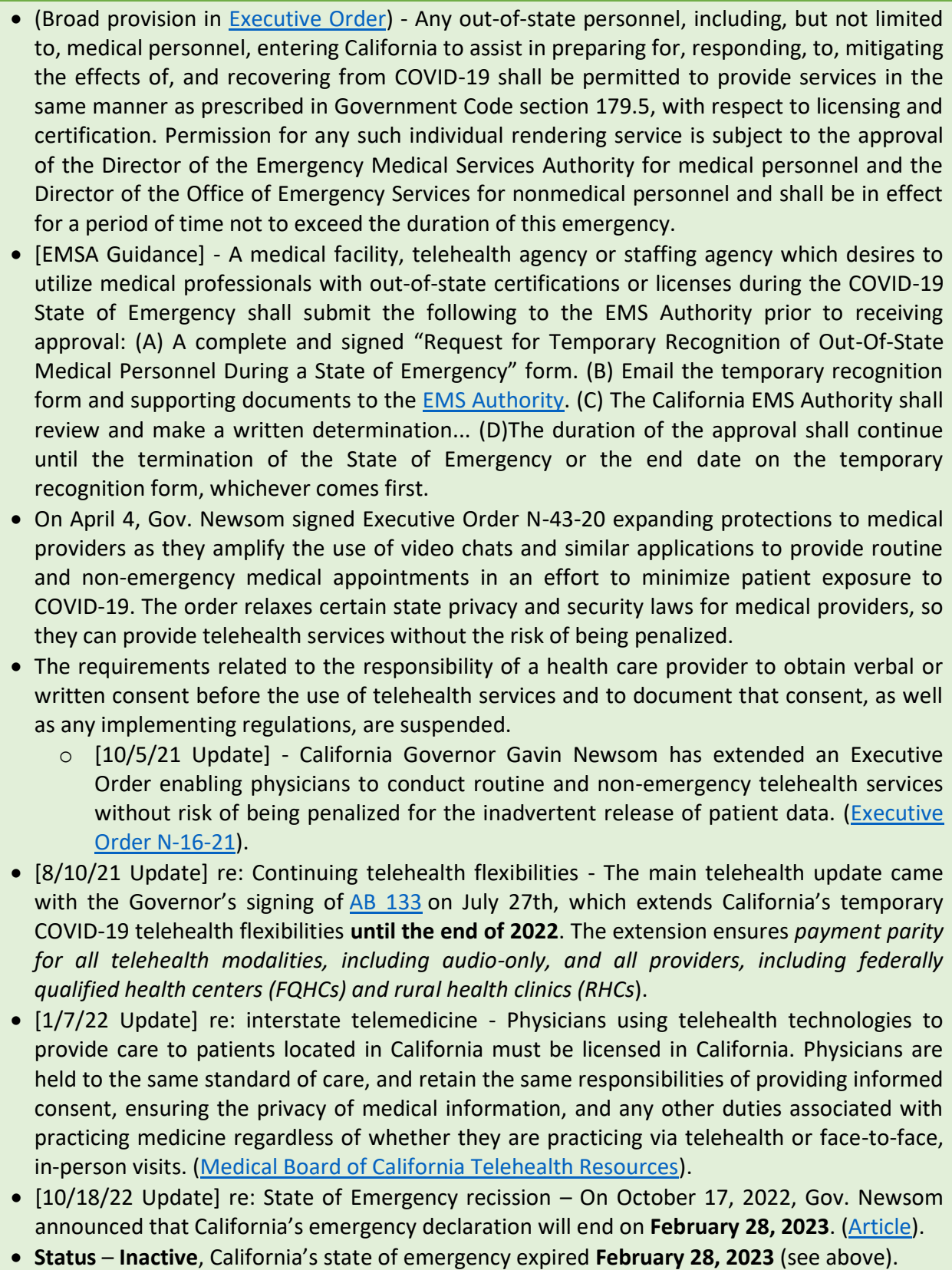 & $\frac{\text { CA AB } 133 \text { Fact Sheet }}{\underline{(\mathrm{CCHP})}}$ \\
\hline Colorado & $\begin{array}{l}\text { - Existing law allows a physician who is not currently licensed in Colorado to provide medical } \\
\text { care in connection with an emergency so long as such services are "gratuitous," that is, free } \\
\text { of charge via } \S 12-240-107(3)(a), \text { C.R.S. The Medical Practice Act also currently allows for a } \\
\text { physician licensed and lawfully practicing medicine in another state or territory without } \\
\text { restrictions to provide occasional services in Colorado through } \S 12-240-107(3)(b) \text {. This } \\
\text { provision does require that the physician not have a regular practice in Colorado and } \\
\text { maintain malpractice insurance. } \\
\text { - Suspension of requirements that patients must be located in Colorado at time of } \\
\text { consultation to expand treatment for traveling Colorado citizens, as currently required under } \\
\S 12-240-107(1)(g), \text { C.R.S., which defines telemedicine as the practice of medicine requiring a } \\
\text { Colorado license to practice telemedicine on patients located in Colorado at time of }\end{array}$ & $\begin{array}{l}\text { DORA Guidance } \\
\frac{\text { Article re: Telehealth }}{\underline{\text { changes }}} \\
\text { CO SB 20-212 }\end{array}$ \\
\hline
\end{tabular}


consultation.

- Re: permanent telehealth changes - On July 6, Colorado Governor Jared Polis signed SB 20-

212 , expanding access to telehealth for Colorado residents by prohibiting insurers from requiring an established in-person practitioner/patient relationship or imposing location or additional licensure requirements, as well as preventing limitations on the use of HIPAAcompliant technologies to deliver telehealth.

- Status - Inactive, Colorado's State of Emergency was rescinded on July 8, 2021, per 7/8 announcement.

- [EO 7G] - Suspends the licensure/certification/registration requirements in § 19a-906(a)(12) - which establishes who may qualify as a "telehealth provider" in Connecticut - for telehealth providers enrolled in Medicaid or in-network in fully-insured commercial plans, in accordance with orders issued by the Commissioner of the Department of Public Health (DPH).

Section 5(b) of Executive Order $7 \mathrm{G}$ allows a clinician licensed in another state to treat someone in CT through telehealth without getting a license in CT. [CT.gov]

- Re: licensure by endorsement - Existing Connecticut law provides that "Department of Public Health may establish a process of accepting an applicant's license from another state and may issue that applicant a license to practice medicine in the state without examination, if certain conditions are met" (Conn. Gen. Stat. § 20-12)

- Re: originating sites - Waiving the homebound requirements for all otherwise coverable medical telemedicine services; Addition of specified "New Patient" Evaluation and Management (E\&M) Services; and Waiving the originating site requirements for psychiatric diagnostic evaluations.

- [EO 7G] Re: telemedicine modality - The order expands Medicaid and commercial health insurance telehealth coverage to audio-only telephone.

- Re: State of Emergency extension - On July 14, 2020, Gov. Lamont signed Executive Order $7 \mathrm{HHH}$, which extends the suspension of the requirements of licensure for physicians and PAs for six months [January 14, 2021] unless earlier modified or terminated.

- Re: telemedicine waiver extensions - CT HB 6001, which was signed into law July 31, 2020, extends Gov. Lamont's emergency orders regarding telemedicine until March 15, 2021, including expanding the type of healthcare professionals that can provide telehealth services to dentists, genetic counselors, and occupational or physical therapist assistants, among others; allowing audio-only telemedicine modalities, and prohibiting insurers from reducing reimbursement for telemedicine services.

- [3/16/21 Update] re: telemedicine waiver extensions - On March 14, 2021, Gov. Lamont issued Executive Order No. 10C that extends the act's expiration date to April 20, 2021.

- [5/14/21 Update] re: two-year waiver extension - On May 10, 2021, Gov. Lamont signed CT HB 5596, which, among other things, allows for physicians licensed out of state to provide services via telemedicine to Connecticut residents for two years. Requires any Connecticut entity, institution, or provider who contracting with an out-of-state provider to verify the provider's credentials and confirm they have professional liability insurance. Bill allows audio-only modalities when appropriate, also limited to a two-year time frame. (Article).

- [7/27/21 Update] re: status of waivers - The executive order that allowed a physician or PA licensed in another state to practice in Connecticut without a Connecticut license expired on July 20, 2021. The order did not distinguish between in-person and telehealth. Public Act 21-9 (HB 5596) authorizes the Commissioner of Public Health to issue an order allowing an out of state licensed physician or PA to provide services via telehealth without obtaining a Connecticut license through June 30, 2023. However, there is no such order in place at this time.

- [12/23/21 Update] re: new waivers - As COVID-19 cases and hospitalizations rise, the Connecticut Department of Public Health is waiving state license requirements for certain out-of-state health care workers looking to practice in Connecticut in an effort to combat staffing shortages... This order will suspend for 60 days the state's requirements for licensure, certification or registration requirements for health care workers who have the appropriate credentials in another U.S. state or territory. It will not extend past February 15 if the state's public health emergency is not extended... Applies to: physicians, PAs, APRNs... (Article).

- [4/15/22 Update] re: recission of waiver - "In accord with Special Act 22-1, Executive Order 14 D will expire on April 15, 2022, ending the modification of various provisions of the General Statutes governing the licensure, permitting of health care professionals and supervision of various health care professionals. The following statutory requirements modified by the Executive Order shall no longer be modified and will be in full effect on April 15, 2022." (DPH Guidance).

Article re:

Telemedicine

Executive Order 7G

Conn. Gen. Stat. § $\underline{20-12)}$

CMAP Telemedicine Guidance

CT HB 6001

Article re: $2^{\text {nd }}$

Telemedicine

Extension

Executive Order $\underline{7 \mathrm{HHH}}$

DPH Commissioner's Order 11/2/22 


\begin{tabular}{|c|c|c|}
\hline & $\begin{array}{l}\text { - [3/1/23 Update] re: out-of-state mental and behavioral health care providers - "I hereby } \\
\text { authorize the following health care providers appropriately licensed, certified or registered in } \\
\text { another state or territory of the United States or the District of Columbia to deliver mental } \\
\text { health and behavioral health care and services via telehealth... psychologists, marital and } \\
\text { family therapists, marital and family therapy associates, clinical social workers... [APRNs]... } \\
\text { certified as a Psychiatric-Mental Health Nurse Practitioner... [PAs]... with a Certificate of } \\
\text { Added Qualifications in Psychiatry..." OOS providers must register with CT DPH, follow CT } \\
\text { law, and submit an application within } 30 \text { days of enrolling. (DPH Commissioner's Order } \\
11 / 2 / 22 \text { ). } \\
\text { - Status - Inactive, the out-of-state waiver expired April } 15,2022 \text {, "The Connecticut } \\
\text { Department of Public Health (DPH) has further extended its temporary waiver of the state's } \\
\text { license requirements for certain out-of-state health care professionals looking to practice in } \\
\text { Connecticut to April } 15 \text {. (DPH Guidance). } \\
\text { - However, OOS mental and behavioral health care providers that are registered with the } \\
\text { state's Department of Public Health may practice via telemedicine until September } \mathbf{3 0 , 2 0 2 3} \\
\text { per DPH Commissioner's Order } 11 / 2 / 22 \text {. }\end{array}$ & $\frac{\text { DPH Commissioner's }}{\underline{\text { Orders }}}$ \\
\hline Delaware & 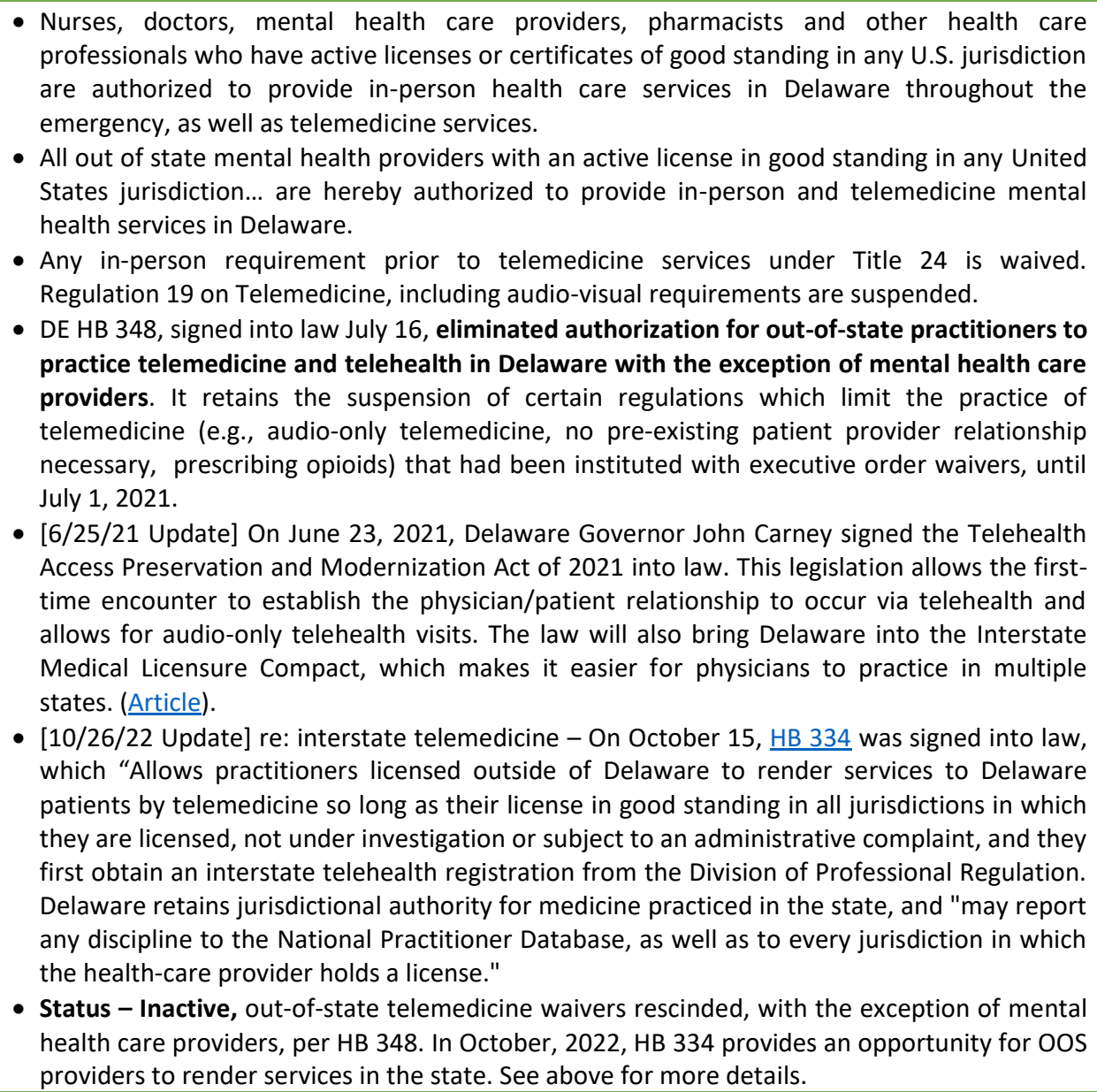 & $\frac{\text { Out of State Medical }}{\underline{\text { Personnel Form }}}$ \\
\hline Florida & $\begin{array}{l}\text { - On March 16, 2020, Florida's Surgeon General issued an Emergency Order that allows certain } \\
\text { out-of-state health care professionals to temporarily provide telehealth services to persons } \\
\text { in Florida in order to prepare for, respond to, or mitigate the effects of COVID-19. The Order } \\
\text { also allows certain Florida licensed physicians to use telehealth services instead of in-person } \\
\text { examinations in limited circumstances. } \\
\text { - For purposes of preparing for, responding to, and mitigating any effect of COVID-19, health } \\
\text { care professionals not licensed in this state may provide health care services to a patient in } \\
\text { this state using telehealth... for a period not to exceed } 30 \text { days unless extended by order of } \\
\text { the State Surgeon General. In addition to the allowed professions under Department of } \\
\text { Health Emergency Order 20-002, this exemption shall apply to the following out of state } \\
\text { health care professionals holding a valid, clear, and unrestricted license in another state or } \\
\text { territory in the United States who are not currently under investigation or prosecution in any } \\
\text { disciplinary proceeding in any of the states in which they hold a license... physicians, } \\
\text { osteopathic physicians, PAs, and APRNs licensed in Florida... designated... as a controlled } \\
\text { substance prescribing practitioner... may issue a renewal prescription for a controlled }\end{array}$ & $\begin{array}{c}\text { Article re: } \\
\text { Telemedicine }\end{array}$ \\
\hline
\end{tabular}


substance listed as Schedule II, Schedule III, or Schedule IV... only for an existing patient for the purpose of treating chronic nonmalignant pain without the need to conduct a physical examination of the patient. These practitioners may only substitute telehealth services for the physical examination.

- During the 2019 legislative session, Florida passed a law authorizing out-of-state health care practitioners to perform telehealth services for patients in Florida. Signed by the Governor on June 25, 2019, this law became effective on July 1, 2019.

- [6/29/21 Update] re: Recission of waivers - But after Gov. Ron DeSantis let an executive order declaring a public-health emergency expire [6/26/21], many regulatory flexibilities that health-care providers received during the pandemic, including flexibilities related to telehealth, also expired. As of $6 / 26$, telephones no longer are an acceptable platform for delivering telehealth services to non-Medicare patients in Florida. Physicians also cannot use telehealth to prescribe controlled substances to existing patients for treating chronic non-malignant pain. Also, physicians cannot use telehealth to recertify medical-marijuana patients. (Article).

- [7/1/21 Update] re: waiver recission - Out-of-state health care practitioners are no longer authorized to perform telehealth services for patients in Florida unless they become licensed or registered in Florida.

- Qualified physicians are required to conduct an in-person physical examination to issue a physician certification for any patient.

- Controlled substance prescribers are required to conduct an in-person physical examination to issue a renewal prescription for a controlled substance. (FBOM Guidance).

- Florida Law $\S 2019-137$ : (a) A health care professional not licensed in this state may provide health care services to a patient located in this state using telehealth if the health care professional registers with the applicable board, or the department if there is no board, and provides health care services within the applicable scope of practice established by Florida law or rule.

- Status - Florida's temporary waivers are inactive, because Florida's State of Emergency expired June 26, 2021 (EO 21-94). However, out-of-state professionals can provide telemedicine services to Florida residents if they are registered with the Medical Board per Florida Law § 2019-137.

- Medical Board Emergency Practice Permits for Telemedicine: On March 5, 2020, the Georgia Composite Medical Board announced that it would issue emergency practice permits to previously unlicensed physicians, physician assistants, advance practice registered nurses, and respiratory care professionals who wish to practice medicine during the COVID-19 emergency response with the Board's approval of the application; valid for 90 days or when the governor lifts the statement of emergency.

- Re: permanent out-of-state telemedicine - Existing Georgia law provides that "The [Medical] Board is authorized to issue telemedicine licenses to physicians who are licensed in other states but not licensed in Georgia if... (1) Hold a full and unrestricted license to practice medicine in another state; (2) Not have had any disciplinary or other action taken against him or her by any other state or jurisdiction; and (3) Meet such other requirements established by the board pursuant to subsection (c) of this Code section as deemed necessary by the board to ensure patient safety. (GA Code $\S 43-34-31.1$ ).

- The Board issued Ga. R \& Regs. § 360-3-0.10-.08 allowing for electronic prescribing during the emergency. This modification allows DEA registered practitioners to issue prescriptions for controlled substances for patients for whom they have not conducted an in-person medical evaluation.

- [6/25/21 Update] re: establishing patient-physician relationship and prescribing - In May, 2021, Governor Kemp enacted legislation to prevent insurance companies from mandating a patient receive an in-person consultation before seeing a health care provider virtually. The law also says insurers can't place additional restrictions on prescribing medications through telehealth visits. (Article).

- [8/10/21 Update] re: license flexibility - “...Georgia Composite Medical Board is authorized to grant temporary licenses to physicians who apply for a temporary medical license and are currently licensed as a physician in good standing by equivalent boards in other states to assist with the needs of the State of Emergency for Continued COVID-19 Economic Recovery" per EO 7.22.21.02.

- Status - Inactive, licensing waivers expired on April 15, 2022, with the expiration of Georgia's State of Emergency. However, Georgia issues telemedicine licenses for oOS physicians, see above for more information.

Guam

- Existing Guam Code allows physicians that are licensed somewhere in the United States to $\underline{\text { FL DOH Guidance }}$

Article re:

Telemedicine

Waivers Rescinded

§ 2019-137 re:

Permanent OOS

Telemedicine

Additional FL OOS Telemedicine FAQs

State Resource Page

Article re:

Telemedicine

GA Code $\S 43-34-$ $\underline{31.1}$

Emergency Practice Application

GA Executive Orders

State Resource Page

10 GCA $\S 12202(b)$ 


\begin{tabular}{|c|c|c|}
\hline & practice telemedicine (10 GCA $\S 12202(b))$. & $\frac{\text { Territory Resource }}{\underline{\text { Page }}}$ \\
\hline Hawaii & 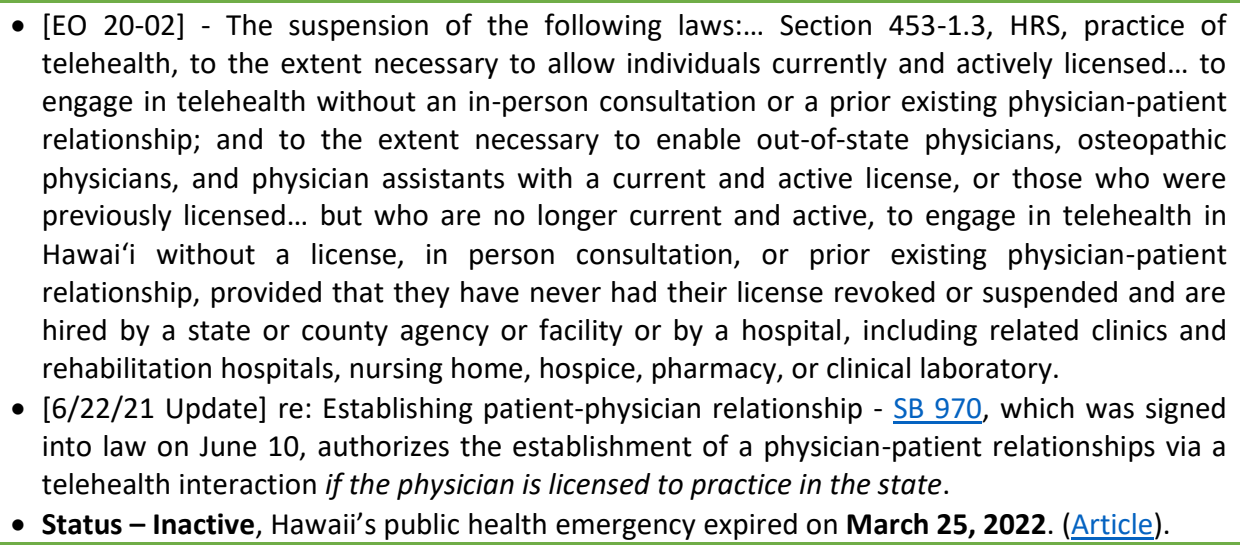 & $\frac{\text { Executive Order 20- }}{\underline{02}}$ \\
\hline Idaho & 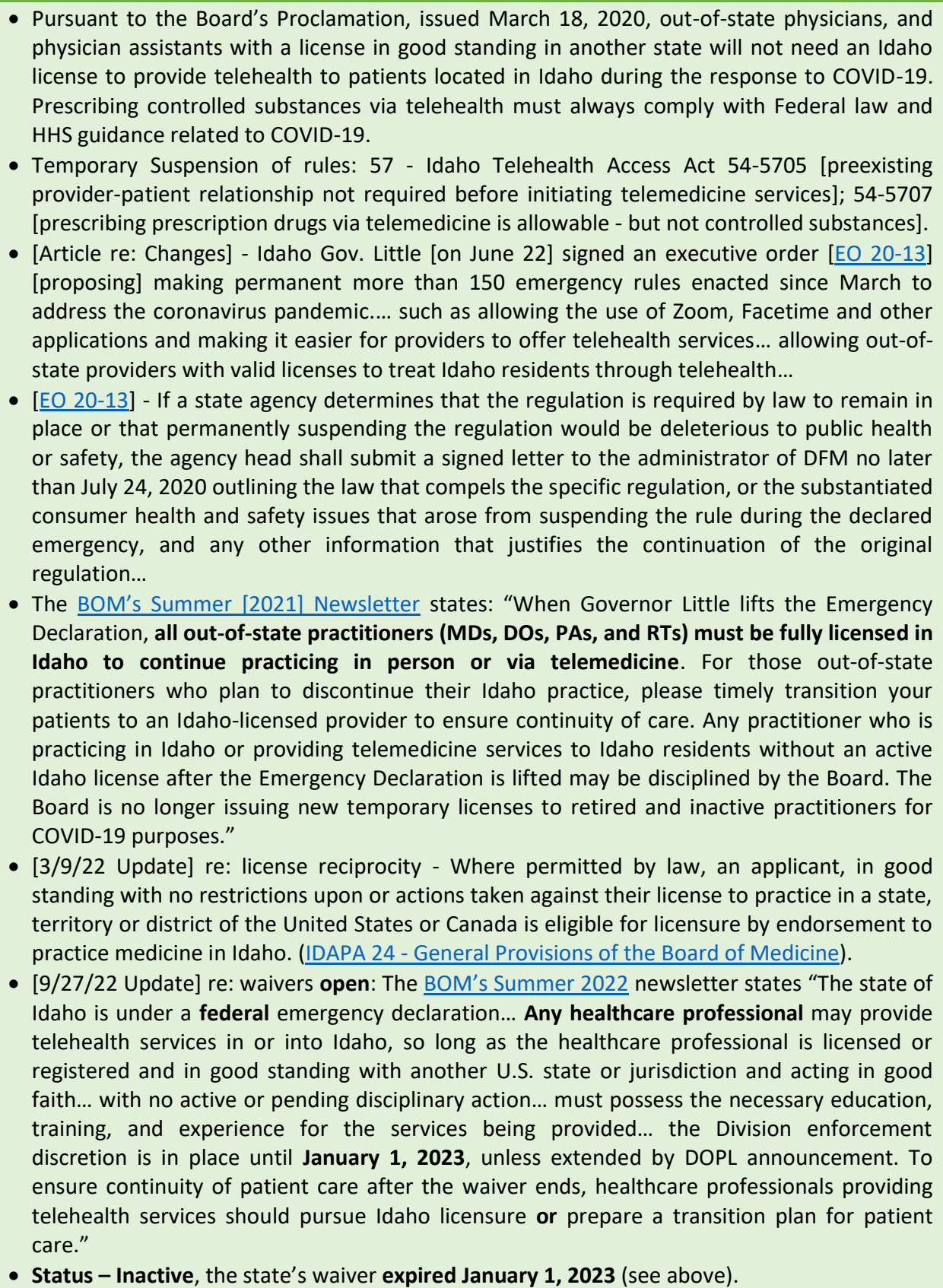 & $\begin{array}{l}\text { Board of Med Proc. } \\
\frac{\text { Gov's Proc. (4/3) }}{\frac{\text { Idaho Telehealth }}{\text { Access Act }}} \\
\text { Article re: Changes } \\
\text { EO 20-13 } \\
\underline{\text { Gov's Proc. (6/11) }} \\
\underline{\text { Idaho Admin. Rules }} \\
\underline{\text { Board of Medicine) }}\end{array}$ \\
\hline Illinois & $\begin{array}{l}\text { - The IDFPR interprets Executive Order } 2020-9 \text { to permit an out-of-state health care provider } \\
\text { not licensed in Illinois to continue to provide health care services to an Illinois patient via } \\
\text { telehealth where there is a previously established provider/patient relationship. The }\end{array}$ & $\underline{\text { IDFPR Clarification }}$ \\
\hline
\end{tabular}


Department deems such a provider to be "authorized to practice in the State of Illinois" pursuant to Section 5 of the Executive Order without further need to obtain licensure in Illinois.

- "Telehealth Services" are expanded to include all health care, psychiatry, mental health treatment, substance use disorder treatment, and related services provided to a patient regardless of the patient's location via electronic or telephonic methods including, for example, FaceTime, Facebook Messenger, Google Hangouts, or Skype.

- Re: Origination sites - Under the amended rules, any site that allows for the patient to use a communication or technology system as defined above may be an originating site, including a patient's place of residence located within the state of Illinois or other temporary location within or outside the state of Illinois.

- Re: insurers - Health insurers ("Insurers") may not impose: Utilization review requirements... Prior authorization requirements for in-network providers providing Telehealth Services related to COVID-19... Cost-sharing obligations for Telehealth Services provided by in network providers. Insurers must cover the costs of Telehealth Services rendered by innetwork providers for medically necessary covered services... May establish reasonable requirements and parameters for Telehealth Services.

- [1/4/22 Update] - Re: interstate telemedicine - Must have an IL medical license. An out-ofstate person providing a service to a patient in IL through telemedicine submits himself or herself to the jurisdiction of the courts of IL. IL Compiled Statutes, Chapter 225, 60/49.5(e).

- Status - Inactive, according to the $1 / 10 / 22$ IDFPR Guidance, the out-of-state telehealth waiver, for established patients only, expired May 31, 2022.

- (Broad provision in Executive Order 20-05) - Suspension of the requirement that a healthcare provider hold an Indiana license if he or she: (1) has an equivalent license from another State, and (2) is not suspended or barred from practice in that State or any State.

- The Initial Telemedicine Provider Certification Request must be completed and filed with the Indiana Professional Licensing Agency before the provider may establish a provider-patient relationship or issue a prescription under IC 25-1-9.5-8 for an individual located in Indiana. Note however, that a provider that practices predominantly in Indiana is not required to file this certification.

- Re: Mental health - Pursuant to Executive Order 20-05, all licensed mental health professionals in the State of Indiana are permitted to conduct their work via telehealth. All statutes and rules that are applicable during remote practice must still be observed; however the requirement that the patient be physically present with the professional is suspended until the end of the public health crisis.

- Re: chronic pain, controlled substances and telemedicine guidelines - The directive also waives the prohibition against audio-only telemedicine services and allows for physical, speech and occupational therapists to provide telemedicine services, but only when using secure videoconferencing, interactive store and forward technology or remote patient monitoring technology. In addition, those DEA-registered providers who have not conducted an in-person medical evaluation of a patient may issue a prescription to that patient for any schedule II-V controlled substance as long as the prescription is issued for a legitimate medical purpose, the telemedicine communication is conducted using an audio-visual, realtime, two-way interactive communication system and all other applicable state and federal laws are followed.

- [EO 20-45] - As provided by Executive Orders 20-13... any individual... who received an initial and/ or subsequent 90-day temporary authorization to provide health care in the State of Indiana in response to this public health emergency because he or she was not currently licensed to practice in the state, either because their Indiana license is no longer active or they are licensed by another state, is granted an additional 90-day authorization to continue to provide health care services during this public health emergency. All application procedures for reinstatement or approval will be reinstituted and must be followed upon expiration of these temporary licenses or the lifting of the COVID-19 public health emergency.

- Re: out-of-state registry - According to the IPLA, "The State of Indiana has created a registry of individuals who do not hold a valid license to practice in Indiana but can be mobilized to help fight COVID-19 by issuing temporary permits to practice. Any individual who utilizes the registry may work initially for $\mathbf{9 0}$ days (extendable in $\mathbf{3 0 - d a y ~ i n c r e m e n t s ) ~ o r ~ u n t i l ~ t h e ~ p u b l i c ~}$ health emergency is over. Once the emergency is over, their license will expire, and all existing application procedures must be followed such as taking the appropriate licensure exam and passing a criminal background check. This registry will be open to: Out-of-state healthcare practitioners; retired healthcare professionals; and recent graduates of accredited medical, registered nursing, pharmacy, physician assistant, and respiratory care
EO 2020-09

Article re: Telehealth

Article re: Origination Site

$\underline{\text { IL Executive Orders }}$

$\underline{\text { State Resource Page }}$

Executive Order 20 $\underline{05}$

PLA Guidance

Initial Telemedicine Provider Certification Request

$\underline{\text { IC } \S 25-1-9.5-8}$

Article re: Chronic pain, controlled substances and telemedicine guidelines

Executive Order 20$\underline{13}$

Executive Order 20 $\underline{45}$

IC 25-1-9.5-9 (re: interstate telemedicine) 
programs."

- [1/6/22 Update] re: interstate telemedicine - Indiana code provides for out-of-state physicians to provide care for Indiana patients - "A practitioner who is physically located outside Indiana is engaged in the provision of health care services in Indiana when the practitioner: (1) establishes a provider-patient relationship under this chapter with; or (2) determines whether to issue a prescription under this chapter for an individual who is located in Indiana. (b) A practitioner described in subsection (a) may not establish a providerpatient relationship... [unless they] have certified in writing to the Indiana professional licensing agency, in a manner specified by the Indiana professional licensing agency, that the practitioner and the practitioner's employer or practitioner's contractor agree to be subject to: (1) the jurisdiction of the courts of law of Indiana; and (2) Indiana substantive and procedural laws... (IC 25-1-9.5-9).

- [3/31/22 Update] re: Emergency License Registry - On March 21, 2022, Indiana's Professional Licensing Agency (PLA) issued a bulletin clarifying that the recently signed $\mathrm{HB}$ 1003 extends the [out-of-state] healthcare registry through the duration of the COVID-19 public health emergency declared by the U.S. Department of Health and Human Services."

- Status - Active, through the declaration of the national PHE, which will expire on May 11, 2023.

- A physician may practice medicine/telemedicine in lowa without an lowa medical license on a temporary basis to aid in the emergency, if a physician holds at least one active medical license in another United State jurisdiction, and all medical licenses held by a physician in other United States jurisdictions are in good standing, without restrictions or conditions. All rules which establish preconditions, limitations, or restrictions on the provision of telehealth or telemedicine services in lowa are temporarily suspended...

- [Covid-19 Emergency Proclamation] - Telemedicine and Telehealth Services: All rules which establish preconditions, limitations, or restrictions on the provision of telehealth or telemedicine services in lowa, including the use of audio-only telephone transmissions, continue to be suspended. All rules which require face-to-face interactions with health care providers, and impose requirements for residential and outpatient substance use disorder treatment and for face-to-face visitations, continue to be suspended.

- [3/7/22 Update] re: grace period - The lowa Board of Medicine announced that although the emergency proclamation expired on February 15, the Board is authorizing a grace period to avoid disruptions in staffing and patient care. Physicians have 90 days (May 17, 2022) to obtain licensure in lowa to comply with the Board's normal licensure requirements. (Article).

- Status - Inactive, out-of-state waivers expired February 15, 2022, per Gov. Reynolds' 2/3 Announcement. However, there is a grace period in effect until May 17, 2022; please see above.

- Gov. Laura Kelly on March 19 announced she had issued executive orders [EO 20-08] to expand the use of telemedicine and waive restrictions on motor carriers who are delivering relief for COVID-19. Out-of-state doctors may provide telemedicine services in Kansas if they are licensed in another state, provided the physician holds an unrestricted license and is in good standing. All physicians are encouraged to utilize telemedicine, including those under self-quarantine.

- Every physician treating a patient through telemedicine shall conduct an appropriate assessment and evaluation of the patient's current condition and document the appropriate medical indication for any prescription issued.

- Passed and signed KS HB 2016, which says, in part "A physician may issue a prescription for or order the administration of medication, including a controlled substance, for a patient without conducting an in-person examination of such patient. (b) A physician under quarantine, including self-imposed quarantine, may practice telemedicine. (c) (1) A physician holding a license issued by the applicable licensing agency of another state may practice telemedicine to treat patients located in the state of Kansas, if such out-of-state physician: (A) Advises the state board of healing arts of such practice in writing and in a manner determined by the state board of healing arts; and (B) holds an unrestricted license to practice medicine and surgery in the other state and is not the subject of any investigation or disciplinary action by the applicable licensing agency..."

- [1/22/21 Update] Re: controlled substances, establishing physician/patient relationship - SB 14 , signed into law January 25 , allows physicians to issue prescriptions (including for controlled substances) without conducting an in-person examination. It also extends the ability for out-of-state practitioners in good standing and without disciplinary or investigation actions to practice telemedicine on Kansas patients until March 31, 2021, provided that they notify the Board in writing in a manner determined by the Board. Lastly, the bill gives the Board flexibility to extend these waivers to other healthcare professionals. (Article).

IN PLA Telemedicine Registry

IN Executive Orders

IPLA Bulletin re: Registry Extension

$\underline{\text { State Resource Page }}$

Board of Med

Emergency

Declaration (3/16 \& 4/27)

Governor's Press Release

$\underline{\text { State Resource Page }}$

Article re: Executive Orders

Executive Order 20$\underline{08}$

(NEW) Telemedicine Waiver

KS HB 2016 


\begin{tabular}{|c|c|c|}
\hline & $\begin{array}{l}\text { - [9/14/21 Update] re: Permanent out-of-state telemedicine - "Notwithstanding any other } \\
\text { provision of law, a physician holding a license issued by the applicable licensing agency of } \\
\text { another state or who otherwise meets the requirements of this section may practice } \\
\text { telemedicine to treat patients located in the state of Kansas, if such physician receives a } \\
\text { telemedicine waiver issued by the state board of healing arts. The state board of healing } \\
\text { arts shall issue such a waiver within } 15 \text { days from receipt of a complete application..." [KS HB } \\
2208] . \\
\text { - }[1 / 19 / 22 \text { Update] re: reinstated waivers - "Any and all provisions in Kansas law are } \\
\text { temporarily suspended... to the extent necessary to allow health care professionals licensed } \\
\text { and in good standing in any state or territory in the United States..." [EO 22-01]. } \\
\text { - [2/22/22 Update] re: long term waiver extension - On January } 21,2022, \text { Gov. Laura Kelly } \\
\text { signed HB } 2477 \text { into law, which, among other things, "Notwithstanding any statute to the } \\
\text { contrary, a healthcare professional licensed and in good standing in another state may } \\
\text { practice such profession in the state of Kansas for the purpose of preparing for, responding } \\
\text { to or mitigating any effect of COVID-19..." } \\
\text { - Status - Inactive, the reinstated Kansas state of emergency expired January 20, 2023, per HB } \\
2477 . \text { (See above). } \\
\text { - Further, Kansas allows for OOS telemedicine for physicians that register with the state Board } \\
\text { of Healing Arts, for more information, see above. According to the Telemedicine Waiver, "If } \\
\text { your waiver was issued before May } 1, \text { you will be required to renew during that year's } \\
\text { renewal period. If your waiver is issued after May } 1, \text { you will not be required to renew until } \\
\text { the following calendar year. Renewal begins May } 15 \text { of each year. All Telemedicine Waivers } \\
\text { cancel August } 1, \text { if not renewed." }\end{array}$ & $\begin{array}{l}\frac{\text { KS HB } 2208 \text { re: }}{\text { Permanent OOS }} \\
\underline{\text { Telemedicine }}\end{array}$ \\
\hline Kentucky & 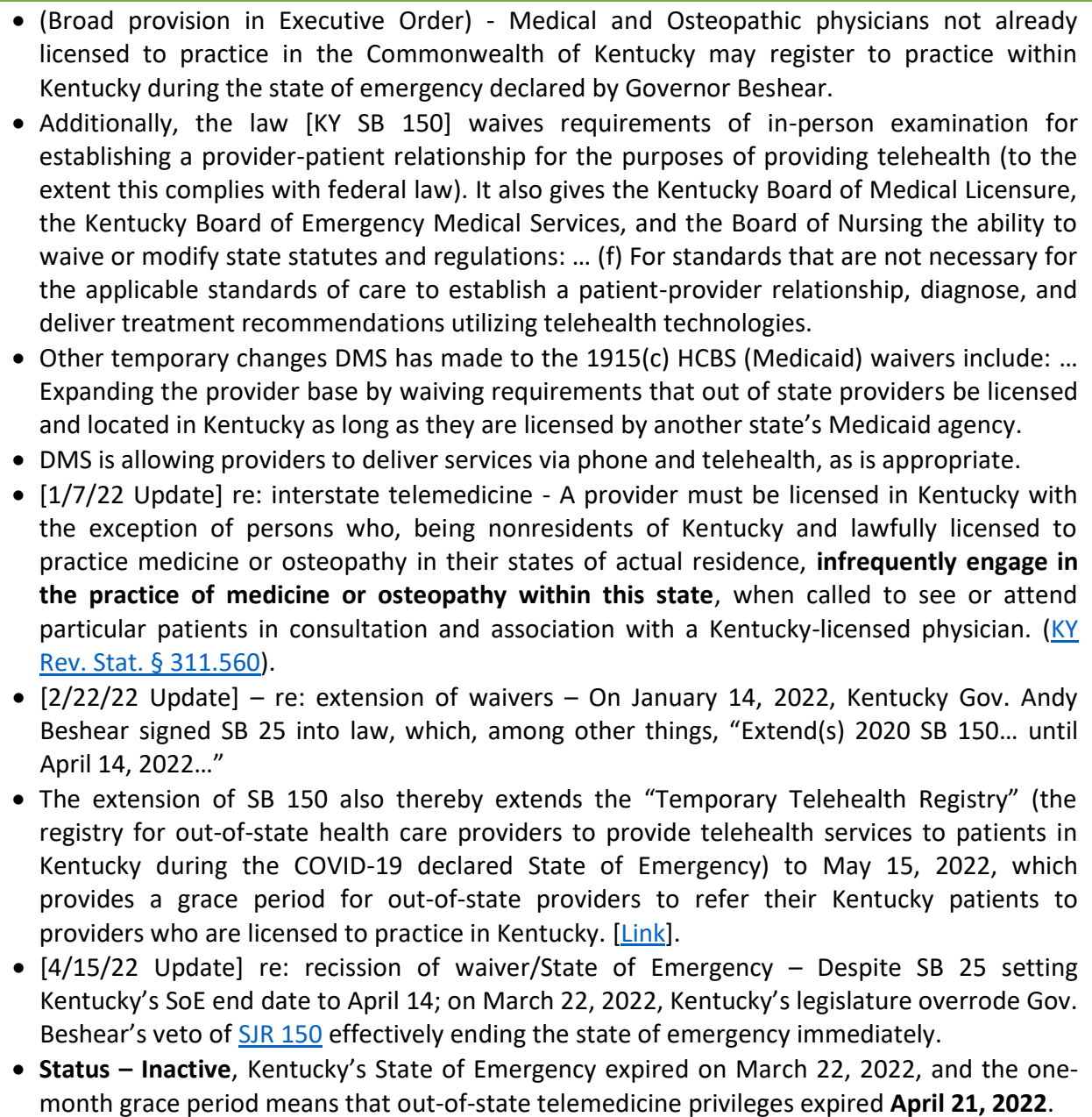 & $\begin{array}{l}\frac{\text { Article re: OOS }}{\underline{\text { Licensing }}} \\
\underline{\text { KY SB 150 }} \\
\text { CFHS Guidance (4/1) }\end{array}$ \\
\hline Louisiana & $\begin{array}{l}\text { - }[18 \text { JBE 2022] - Louisiana state licensure laws, rules, and regulations for medical professionals } \\
\text { and personnel hereby remain suspended for those medical professionals and personnel from } \\
\text { other states or other countries offering medical services in Louisiana to those needing } \\
\text { medical services as a result of this disaster provided that said out-of-state or out-of-country } \\
\text { medical professionals and personnel possess a current medical license in good standing in } \\
\text { their respective state or country of licensure and that they practice in good faith and within } \\
\text { the reasonable scope of his or her skills, training, or ability. }\end{array}$ & $\begin{array}{l}\underline{\text { LSBME OOS }} \\
\underline{\text { Telemedicine Permits }}\end{array}$ \\
\hline
\end{tabular}


- The Louisiana State Board of Medical Examiners has an emergency temporary permit application on their website for licensed out-of-state medical professionals seeking a temporary, voluntary license for an emergency event in the state of Louisiana. While there is no explicit mention of telemedicine, the LSBME has a list of approved out-of-state telemedicine permits, implying it is allowed.

- [Proc. 2020-32] - There is a need to allow for additional telehealth opportunities. To facilitate the provision of telehealth services where available and appropriate, the following guidelines are adopted: $(A)$ The requirement that each state agency or occupational licensing board... regulate the use of telehealth in the delivery of healthcare services within the scope of practice regulated by said agency is suspended. (B) It will not be considered a violation of licensing standards... to provide a service via telehealth. (C) The practice of the provider... must be within the scope of the provider's license, skill, training... (D) Prescribing of any controlled substance via telehealth must be medically appropriate, well-documented and continue to conform to rules applicable to the prescription of such medications.

- [LDH Guidance] Re: modality, origination site - Providers offering services via telemedicine/telehealth must use a secure, HIPAA-compliant platform, if available. If not available, providers may use everyday communication technologies, including audio-only delivery of telemedicine/telehealth services (e.g., telephone) or use of videoconferencing (e.g., Skype, FaceTime) programs that have reasonable security measures, with each recipient's permission. Audio-only delivery is allowed only in situations where an audio/video system is not available or not feasible... There is currently no formal limitation on the originating site (i.e., where the recipient is located) and this can include, but is not limited to, a healthcare facility, a school or the recipient's home. Regardless of the originating site, providers must maintain adequate medical documentation to support reimbursement of the visit.

- [1/4/22 Update] re: interstate telemedicine - The board shall issue a telemedicine license to allow the practice of medicine across state lines to an applicant who holds a full and unrestricted license to practice medicine in another state or territory of the United States. The board shall establish by rule in accordance with the Administrative Procedure Act the requirements for licensure including not opening an office in Louisiana, not meeting with patients in Louisiana, and not receiving calls in Louisiana from patients. The physician, when examining a patient by telemedicine, shall establish a bona fide physician-patient relationship by: (A) Conducting an appropriate examination of the patient as determined by the board. (B) Establishing a diagnosis through the use of accepted medical practices including but not limited to patient history, mental status, and appropriate diagnostic and laboratory testing. (C) Discussing with the patient any diagnosis as well as the risks and benefits of various treatment options. (D) Ensuring the availability for appropriate follow-up care. (E) Fulfilling any other requirements as deemed appropriate and necessary by the board. (LA Revised Statutes § 37:1276.1).

- Status - Inactive, Louisiana's State of Emergency expired on March 16, 2022, per Gov. Bel Edward's $\underline{3 / 14}$ statement. However, the waivers did not immediately close "For an orderly transition and continuity of care for Louisiana citizens, the LSBME will extend the duration of all temporary permits issued during the Covid public health emergency until $\mathbf{9 0}$ days after the termination of the declared health care emergency, whenever that is determined by the governor or the judicial branch of the state of Louisiana." (LBSME Guidance). Therefore, temporary licenses expired June 14, 2022.

- The order signed by Gov. Mills gives greater flexibility to physicians, physician assistants and nurses to practice in Maine. According to the order, those who are licensed in these professions in other states and in good standing can now: (1) Receive an emergency license to provide health care services via telehealth to Maine people with no application fee; (2) See patients via telehealth without obtaining a license if already serving those patients at out-of-state locations; (3) Get their licenses automatically renewed during the state of emergency if their active license is about to expire.

- [3/20 EO] - A physician, physician assistant, or nurse who is licensed and in good standing in another state and has no disciplinary or adverse action in the last ten years involving loss of license, probation, restriction or limitation, and who seeks immediate licensure to assist in the health care response to COVID-19, shall forthwith be issued an emergency Maine license that shall remain valid during the state of emergency. All physicians, physician assistants, or nurses licensed under this provision may provide health care services in-person in Maine or across state lines into Maine using telemedicine or telehealth.

- Re: Telemedicine waivers - Maximize the use of telemedicine and telehealth and eliminates the need for some in-person patient visits for the duration of the emergency by: (1) Allowing voice-only technology to be used; and (2) Suspending any laws or rules related to state
Emergency

Temporary

Application

Proclamation 2020$\underline{32}$

$\underline{\text { LDH Guidance 3/20 }}$

Telehealth Guidance During COVID-19

Pandemic

LSBME Guidance re: Covid Changes

LA Emergency Proclamations

$\underline{\text { LA Revised Statutes }}$

$\S 37: 1276.1$ (re: interstate license)

$\underline{\text { State Resource Page }}$

3/20 Executive Order

Article re: OOS Licensing

Supplemental Order $\underline{3 / 20}$

Executive Order $3 / 24$ 


\begin{tabular}{|c|c|c|}
\hline & $\begin{array}{l}\text { medical record privacy and HIPAA that would interfere with the use of telemedicine and } \\
\text { telehealth technology. } \\
\text { - }[1 / 7 / 22 \text { Update] re: interstate telemedicine - A physician not licensed to practice medicine in } \\
\text { this State may provide consultative services through interstate telehealth to a patient } \\
\text { located in this State if the physician is registered... (Maine Rev. Stat. Ann., Tit. } 32, \S 3300-D \text { ). } \\
\text { - Status - Inactive, the Maine State of Emergency expired June 30, 2021, per } \underline{6 / 11} \\
\text { Proclamation. }\end{array}$ & State Resource Page \\
\hline Maryland & 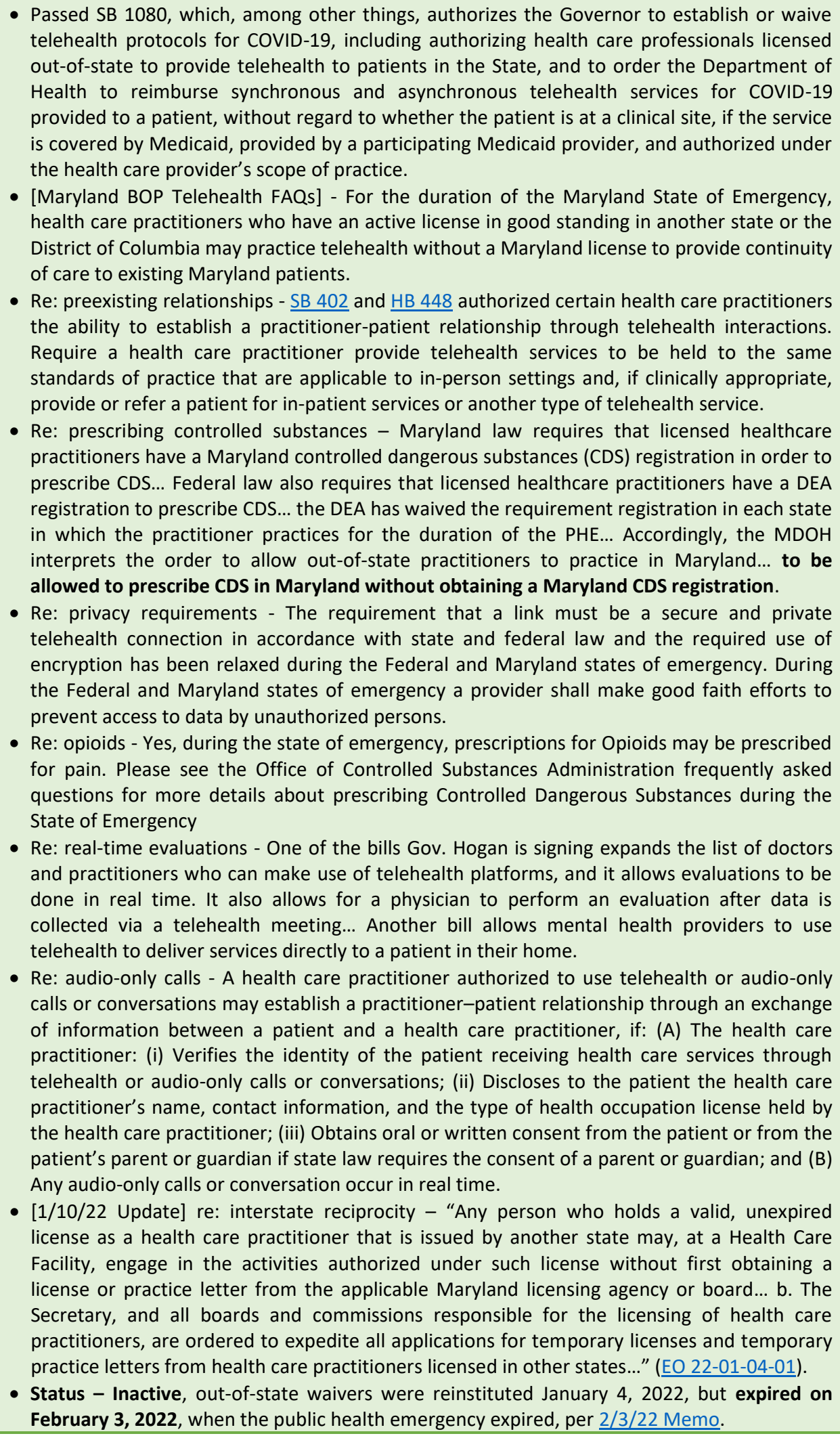 & $\begin{array}{l}\frac{\text { Board of Physicians }}{\text { Guidance re: End of }} \\
\frac{\text { the Maryland State }}{\text { of Emergency }} \\
\frac{\text { MD Health Occ Code }}{\text { § 14-302 re: }} \\
\text { Reciprocal Licensing }\end{array}$ \\
\hline & - Massachusetts' Order offers broad credentialing privileges: "With the Governor declaring a & $\underline{\text { BORIM Press Release }}$ \\
\hline
\end{tabular}




\begin{tabular}{|c|c|c|}
\hline & $\begin{array}{l}\text { State of Emergency, the Board of Registration in Medicine has established an Emergency } \\
\text { Temporary License Application for out-of-state physicians to assist in meeting the increased } \\
\text { demand for physician services in Massachusetts. To qualify for an Emergency Temporary } \\
\text { License a physician must hold an active full, unlimited and unrestricted medical license in } \\
\text { good standing in another U.S. state/territory/district. "Good standing" shall not include a } \\
\text { license that has been revoked, cancelled, surrendered, suspended, or is subject to } \\
\text { disciplinary restrictions." } \\
\text { - Re: preexisting relationships - The new rule approved by the board makes it explicit that a } \\
\text { doctor can treat a patient whom he or she has never seen in person as long as the physician } \\
\text { considers it best for the patient during the health crisis. } \\
\text { - Re: coverage rates - Gov. Charlie Baker ordered all commercial insurers, self-insured plans } \\
\text { and state health plans to cover all clinically appropriate telehealth services and at the same } \\
\text { rate as in-person care. The order specifies that all payers in the state "are required to allow } \\
\text { all in-network providers to deliver clinically appropriate, medically necessary covered } \\
\text { services to members via telehealth." } \\
\text { - Re: uninsured populations - Doctor on Demand has struck a deal with the state of } \\
\text { Massachusetts to provide free telehealth visits to the state's uninsured during the } \\
\text { coronavirus pandemic... Uninsured and Medicaid patients with symptoms of covID-19 or } \\
\text { have been targeted as needing care as the result of contact tracing are eligible to receive the } \\
\text { service, which will be available } 24 / 7 \text {, at no charge. } \\
\text { - [5/18/21 Update] Re: end of State of emergency - And the state of emergency that's been in } \\
\text { place since March } 10,2020, \text { will be lifted June 15, [2021], Gov. Charlie Baker announced } \\
\text { [May } 17 \text { ]. (Article). } \\
\text { Status - Inactive, the state of emergency was rescinded on June 15, 2021, ending the } \\
\text { temporary license waiver. (Article). }\end{array}$ & $\begin{array}{l}\frac{\text { Article re: Preexisting }}{\underline{\text { relationship }}} \\
\text { requirements } \\
\underline{\text { Article re: Coverage }} \\
\text { Article re: Uninsured }\end{array}$ \\
\hline Michigan & $\begin{array}{l}\text { - Michigan law provides: "Under the circumstances and subject to the limitations stated in } \\
\text { each case, the following individuals are not required to have a license issued under this } \\
\text { article for practice of a health profession in this state: (c) An individual who by education, } \\
\text { training, or experience substantially meets the requirements of this article for licensure while } \\
\text { rendering medical care in a time of disaster..." (MCL } \S 333.16171) \text {. This provision does not } \\
\text { require an individual apply for or be granted an exemption by the Department. } \\
\text { - Re: origination site - Michigan's governor called on health plans to do more to encourage the } \\
\text { use of telehealth and ordered the state Medicaid program to include the home as a } \\
\text { telehealth site. } \\
\text { - [EO 2020-86] All health care providers are authorized and encouraged to use telehealth } \\
\text { services when medically appropriate and upon obtaining patient consent. To facilitate the } \\
\text { provision of telehealth services: (a) Written consent for treatment is not required. A health } \\
\text { care provider may obtain verbal consent... (b) Health care providers engaging in telehealth } \\
\text { services may use asynchronous store and-forward technology for the transmission of } \\
\text { medical information... (c) Remote patient monitoring, which may or may not take place in } \\
\text { real-time, may be conducted as part of telehealth services... (d) A physician is not required to } \\
\text { conduct an in-person examination before prescribing medication or ordering the } \\
\text { administration of medication, including controlled substances except for methadone... } \\
\text { - Re: Rescinding out of state waivers - On July } 13,2020, \text { Gov. Whitmer issued Executive Order } \\
2020-150 \text { to rescind a previous order (Executive Order } 2020-61 \text { ) that had permitted... health } \\
\text { care professionals who are licensed in good standing in other states or United States } \\
\text { territories to practice in Michigan without criminal, civil or administrative/licensure } \\
\text { penalties for lack of Michigan licensure. } \\
\text { - Status - Inactive, out-of-state practice privileges rescinded per EO } 2020-150 \text {. }\end{array}$ & $\begin{array}{c}\frac{\text { Executive Order }}{\underline{2020-86}} \\
\frac{\text { Article re: Rescinding }}{\underline{\text { waivers }}}\end{array}$ \\
\hline Minnesota & $\begin{array}{l}\text { - Minnesota's April } 25 \text { Executive Order provides: "qualified out-of-state healthcare } \\
\text { professionals to render aid in Minnesota to meet the healthcare needs of Minnesotans } \\
\text { during the COIVD } 19 \text { peacetime emergency... (2) Out-of-State Healthcare Professionals who } \\
\text { hold an active, relevant license, certificate, or other permit in good standing issued by a state } \\
\text { of the United States or the District of Columbia... (3) Before rendering any aid... [providers] } \\
\text { must be engaged with a healthcare system or provider, such as a hospital, clinic, or other } \\
\text { healthcare entity, in Minnesota. (4) A [Minnesota] healthcare system or provider must verify } \\
\text { that each Out-of-State Healthcare Professional holds an active, relevant license, certificate, } \\
\text { or other permit in good standing... } \\
\text { - Re: out-of-state telemedicine - Minnesota law provides: "A physician licensed in another } \\
\text { state can provide telemedicine services to a patient in Minnesota if their license has never } \\
\text { been revoked or restricted in any state, they agree to not open an office in Minnesota, meet } \\
\text { with patients in Minnesota, or receive calls in Minnesota from patients and they register with } \\
\text { the state's board. These requirements do not apply in response to emergency medical }\end{array}$ & $\begin{array}{l}\frac{\text { Press Release re: }}{\underline{\text { OOS Waivers }}} \\
\frac{\text { Executive Order 20- }}{\underline{46}} \\
\frac{\text { MN Statute } \S}{\underline{147.032}}\end{array}$ \\
\hline
\end{tabular}




\begin{tabular}{|c|c|c|}
\hline & $\begin{array}{l}\text { conditions, the services are on an irregular or infrequent basis, or the physician provides } \\
\text { interstate telemedicine services in consultation with a physician licensed in Minnesota" (MN } \\
\text { - Rtat. } \S 147.032 \text { ). } \\
\text { Re: establishing patient-physician relationship - Minnesota law provides "that a physician- } \\
\text { patient relationship may be established through telemedicine, and that physicians who } \\
\text { provide services by telemedicine are held to the same standards of practice and conduct as } \\
\text { apply to the provision of in-person services. (MN Stat. } \S 147.033 \text { ). } \\
\text { - Re: telemental health - On April } 6 \text {, Gov. Walz authorized out-of-state mental health providers } \\
\text { to provide telehealth services to Minnesota patients (this waiver appears to be explicitly } \\
\text { limited to mental health professionals). } \\
\text { - Re: Medicaid waivers - On March } 27,2020, \text { CMS approved Minnesota's state Medicaid } \\
\text { waiver request allowing certain flexibilities, including: Temporarily waiving the requirement } \\
\text { that out-of-state providers be licensed in Minnesota. The temporary waiver still requires } \\
\text { minimum data collection about the out-of-state provider, exclusion screening, and no } \\
\text { payments to providers who temporarily enrolled six months after the Public Health } \\
\text { Emergency ends. } \\
\text { - Re: SUD treatment - Minnesota's legislature passed a law that "allows the examination } \\
\text { requirement for prescribing drugs to treat substance use disorder to be met if the } \\
\text { prescribing practitioner performs a telemedicine examination." This provision is time-limited } \\
\text { and terminates } 60 \text { days after the peacetime emergency ends (Laws } 2020 \text {, ch. } 115 \text {, art. } 2, \S \\
30 \text { ). } \\
\text { - Status - Inactive, as of May } 6,2021, \text { out-of-state telehealth registration applications will no } \\
\text { longer be processed. (Minnesota Board of Behavioral Health and Therapy Guidance). } \\
\text { However, out-of-state professionals can provide telemedicine services to Minnesota } \\
\text { residents if they are registered with the Medical Board per Minnesota Statute } \S 147.032 \text {. }\end{array}$ & $\begin{array}{c}\frac{\text { Governor's Press }}{\text { Release }} \\
\frac{\text { Emergency Executive }}{\text { Order 20-28 }} \\
\text { Article re: } \\
\text { Medicaid/Waivers }\end{array}$ \\
\hline Mississippi & $\begin{array}{l}\text { - [10/26/20 Proc.] - As to those out-of-state physicians who currently hold an emergency } \\
\text { license to treat Mississippi patients via telemedicine, such licenses shall remain in force and } \\
\text { effect until January } 31,2021 \ldots \text { those wishing to continue to provide care must submit an } \\
\text { application for a full, unrestricted licensed on or before December } 31,2020 \text {. } \\
\text { - [4/5/20 Proc.] - The Board hereby waives any and all Mississippi licensing requirements for } \\
\text { out of state physicians whose specialty services are determined to be necessary by MSDH } \\
\text { [specifically pulmonologists and nephrologists], provided the out of state physicians holds } \\
\text { an unrestricted license to practice medicine in the state in which the physician practices and } \\
\text { currently is not the subject of an investigation or disciplinary proceeding. } \\
\text { - [3/24/20 Proc.] - Out-of-state physicians may only utilize telemedicine when treating } \\
\text { patients in Mississippi with whom they have a pre-existing doctor-patient relationship. } \\
\text { - Re: pre-existing relationships - The requirement for a preexisting doctor-patient relationship } \\
\text { does not apply for in-state physicians. } \\
\text { - Re: controlled substances - As to those holding a valid unrestricted license to practice } \\
\text { medicine in Mississippi, the emergency telemedicine waiver of the prohibition against } \\
\text { prescribing controlled substances shall remain in effect [10/26/20 Proc.] } \\
\text { - [1/7/22 Update] re: interstate telemedicine - No person shall engage in the practice of } \\
\text { medicine across state lines (telemedicine) in this state, hold himself out as qualified to do the } \\
\text { same, or use any title, word or abbreviation to indicate to or induce others to believe that he } \\
\text { is duly licensed to practice medicine across state lines in this state unless he has first } \\
\text { obtained a license to do so from the State Board of Medical Licensure... (MS Code } \S 73-25- \\
\text { 34). }\end{array}$ & $\begin{array}{c}\text { Supplemental } \\
\text { Proclamation } 4 / 5 / 20\end{array}$ \\
\hline Missouri & $\begin{array}{l}\text { - During this state of emergency in Missouri, physicians and surgeons licensed in another state } \\
\text { can provide care to Missouri citizens, in person or using telehealth options, as long as they } \\
\text { are actively licensed in another state and their license has not been disciplined. } \\
\text { - Re: documentation waivers - The executive order temporarily suspends rules requiring a } \\
\text { physical exam and maintaining a contemporaneous record. } \\
\text { - Re: establishing physician/patient relationship - HB 1682, signed July } 13 \text {, allows physicians } \\
\text { to establish physician-patient relationship via a telemedicine encounter, if the standard of } \\
\text { care does not require an in-person encounter, and in accordance with evidence-based } \\
\text { standards of practice and telemedicine practice guidelines. } \\
\text { - [8/30/21 Update] re: Renewed waivers: I do hereby order suspension of certain statutory } \\
\text { and regulatory provisions related to telemedicine, and I further vest state agencies and } \\
\text { executive boards and commissions with authority to waive or suspend statutory or } \\
\text { regulatory requirements, subject to my approval, where strict compliance would hinder the } \\
\text { State's recovery from COVID-19, and to ease licensing requirements to eliminate barriers to }\end{array}$ & $\begin{array}{c}\text { Article re: Telehealth } \\
\frac{\text { Executive Order 20- }}{\underline{04}} \\
\underline{\text { MO HB } 1682}\end{array}$ \\
\hline
\end{tabular}




\begin{tabular}{|c|c|c|}
\hline & $\begin{array}{l}\text { the provision of health care services and other professions. [EO 21-09]. } \\
\text { - }[1 / 7 / 22 \text { Update] re: interstate telemedicine - In order to treat patients in this state through } \\
\text { the use of telemedicine or telehealth, health care providers shall be fully licensed to practice } \\
\text { in this state... (MO Rev. Stat. Ch. } 191 \S 191.1145 \text { ). } \\
\text { - Status - Inactive, waivers expired December 31, 2021, per EO 21-09, and have not been } \\
\text { renewed. (Press Release). }\end{array}$ & $\underline{\text { State Resource Page }}$ \\
\hline Montana & $\begin{array}{l}\text { - Pursuant to } \S 10-3-118, \mathrm{MCA} \text {, the Montana Department of Labor and Industry may provide } \\
\text { interstate licensure recognition whenever a state of emergency or disaster is in effect by } \\
\text { registering professionals who possesses an active, unrestricted license in another state. } \\
\text { Health care practitioners shall be allowed to perform health care services using all modes of } \\
\text { telehealth, including video and audio, audio-only, or other electronic media... Strict } \\
\text { adherence to the following requirements of board specific telehealth requirements for these } \\
\text { practitioners is suspended. } \\
\text { - Strict compliance with [Montana Code] is suspended to the extent that providers are not } \\
\text { limited for the duration of the emergency to the use of any specific technologies to deliver } \\
\text { telemedicine, telehealth, or telepractice services, and may provide such services using secure } \\
\text { portal messaging, secure instant messaging, telephone conversations, or audio-visual } \\
\text { conversations. To the extent any of these provisions prevent providers from delivering } \\
\text { telemedicine, telehealth, or telepractice services from their or their patients' homes, work, } \\
\text { or other appropriate venue, strict compliance with those provisions is suspended, provided: } \\
\text { (A) To the extent possible, providers must ensure that patients have the same rights to } \\
\text { confidentiality and security as provided during traditional office visits. (B) Providers must } \\
\text { follow consent and patient protocol consistent with those followed during in-person visits... a } \\
\text { pre-existing provider/patient relationship is not required to provide telemedicine, telehealth, } \\
\text { or telepractice services. } \\
\text { - Re: payment parity - The coverage for health care services delivered by telemedicine "must } \\
\text { be equivalent to the coverage for services that are provided in person." } \\
\text { - Status - Inactive, the Montana State of Emergency was rescinded on June 30, 2021, per EO } \\
2021-10 .\end{array}$ & $\frac{3 / 20 \text { Executive }}{\frac{\text { Directive on }}{\text { Telehealth }}}$ \\
\hline Nebraska & 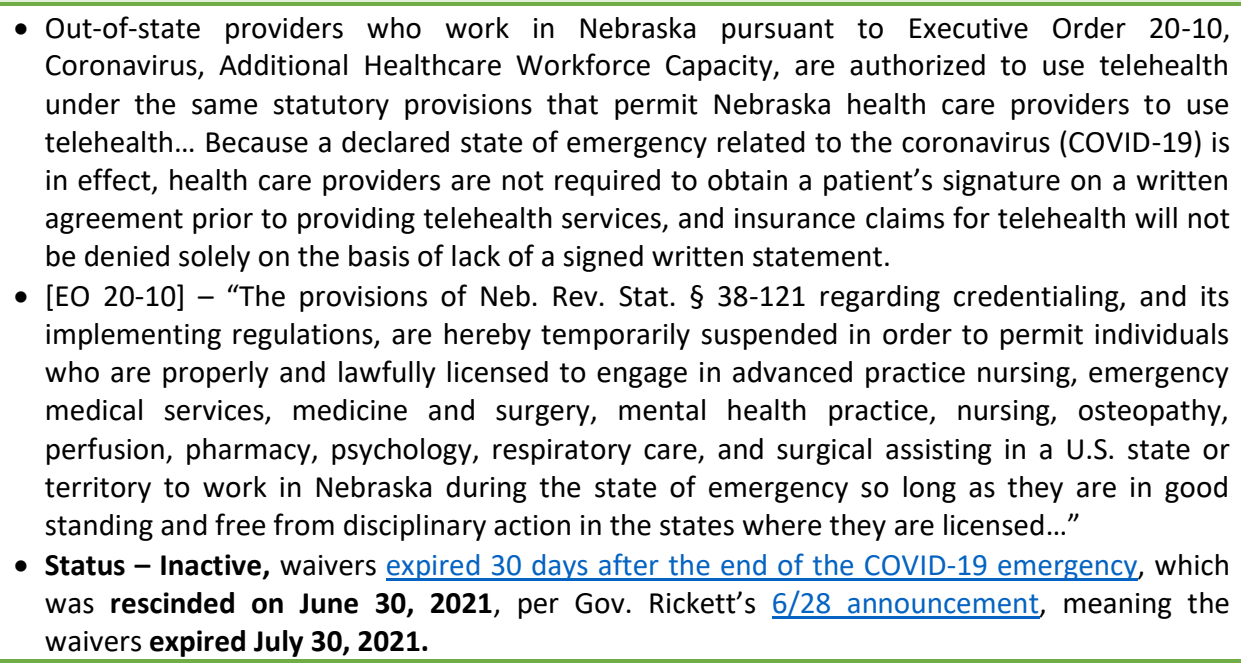 & $\frac{\text { Executive Order 20- }}{\underline{10}}$ \\
\hline Nevada & $\begin{array}{l}\text { - Professional licensing boards regulating providers of medical services shall temporarily waive } \\
\text { certain licensing requirements to allow the practice of currently unlicensed skilled medical } \\
\text { professionals during the pendency of the COVID-19 crisis... including without limitation, } \\
\text { medical doctors, physician assistants... The waiver and exemption of professional licensing } \\
\text { requirements shall apply to qualified providers of medical services during this declared } \\
\text { emergency who currently hold a valid license in good standing in another state, providers of } \\
\text { medical services whose licenses currently stand suspended for licensing fee delinquencies, } \\
\text { providers of medical services whose licenses currently stand suspended for failure to meet } \\
\text { continuing medical education requirements, and providers of medical services who have } \\
\text { retired from their practice in any state with their license in good standing. These waivers and } \\
\text { exemptions shall not apply to persons whose licenses have been revoked or voluntarily } \\
\text { surrendered as a result of disciplinary proceedings. } \\
\text { - [6/22/21 Update] re: audio-only telemedicine/establishing patient-physician relationship - } \\
\text { SB } 5 \text {, which was signed into law on June } 4,2021 \text {, allows the delivery of telehealth services } \\
\text { through audio-only interactions and allows providers to establish a patient relationship } \\
\text { through telehealth, among other actions. } \\
\text { - }[9 / 8 / 21 \text { Update] re: Special licensure - Nevada statute provides for Special Purpose Medical }\end{array}$ & $\begin{array}{c}\frac{\underline{\text { Emergency Directive }}}{\underline{011}} \\
\underline{\text { NV SB 5 }} \\
\text { [MDs]: Emergency } \\
\text { License Application }\end{array}$ \\
\hline
\end{tabular}




\begin{tabular}{|c|c|c|}
\hline & $\begin{array}{l}\text { Licenses that "can be issued to a physician who is licensed in another state to perform any of } \\
\text { the acts described in subsections } 1 \text { and } 2 \text { of NRS } 630.020 \text { by using [telemedicine] if the } \\
\text { physician: i) Holds a full and unrestricted license to practice medicine in that state; ii) Has not } \\
\text { had any disciplinary or other action taken against him or her by any state or other } \\
\text { jurisdiction; and iii) Is certified by a specialty board of the American Board of Medical } \\
\text { Specialties or its successor. (NRS } 630.261 \text { ). } \\
\text { - [5/13/22 Update] re: End of State of Emergency - On May 6, Nevada Gov. Steve Sisolak } \\
\text { announced that he will end Nevada's state of emergency on May 20, 2022. (Article). } \\
\text { - Status - Inactive, Nevada's state of emergency was rescinded May 20, 2022, per Gov. } \\
\text { Sisolak's } 5 / 6 \text { announcement (see above). (Article re: ending emergency). }\end{array}$ & $\begin{array}{l}\frac{\text { Gov. Sisolak rescinds }}{\underline{\text { SoE }}} \\
\text { State Resource Page }\end{array}$ \\
\hline New Hampshire & 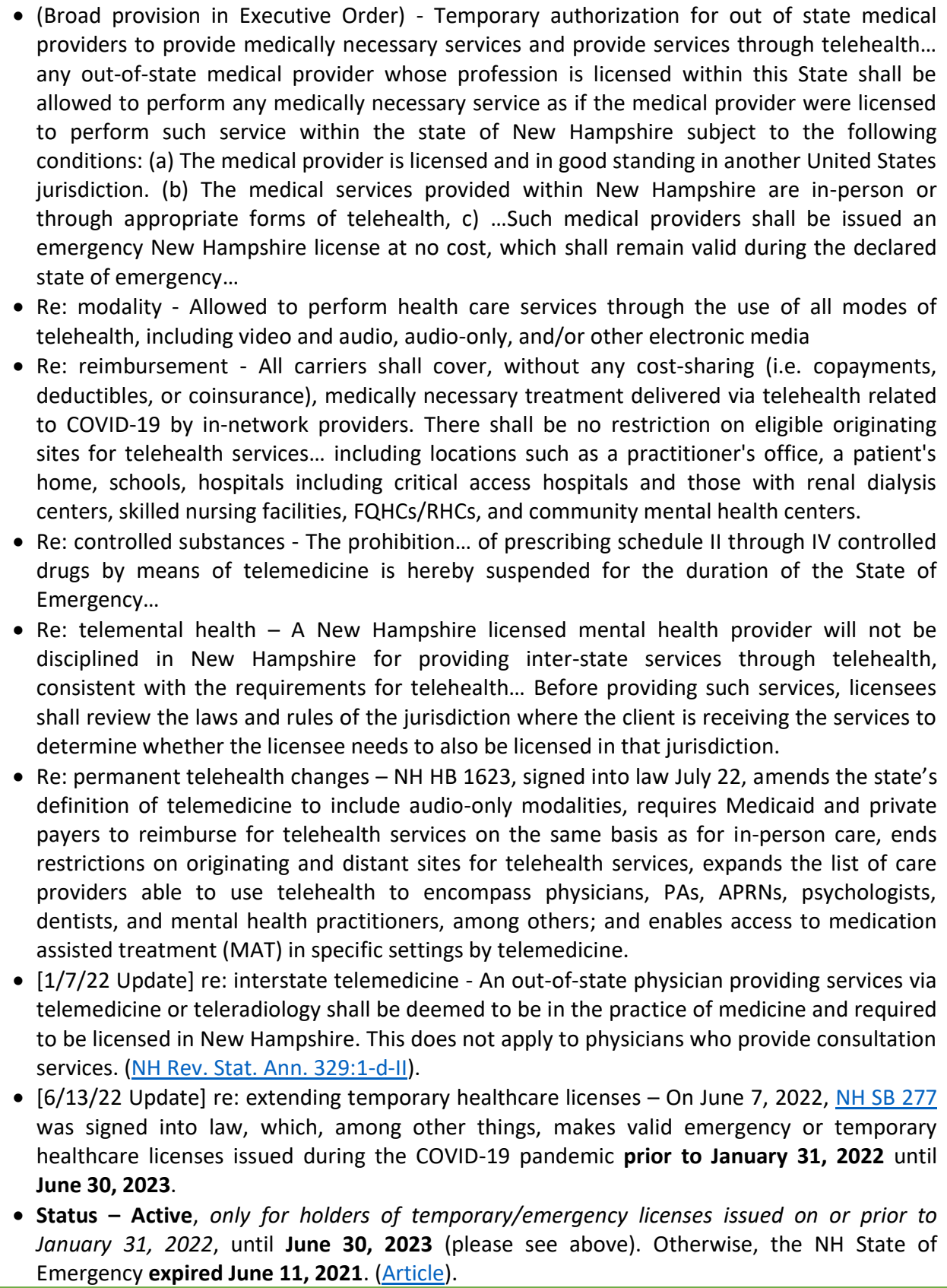 & $\frac{\frac{\text { Board of Mental }}{\text { Health Practice }}}{\text { Guidance }}$ \\
\hline New Jersey & $\begin{array}{l}\text { - In response to the on-going COVID-19 state of emergency, the State of New Jersey has } \\
\text { waived certain regulatory provisions regarding licensure of health care practitioners through } \\
\text { reciprocity. These waivers will allow health care providers licensed in other states to obtain } \\
\text { New Jersey temporary licensure and provide services to New Jersey patients either through } \\
\text { telemedicine, pursuant to P.L. } 2017, \text { c. } 117 \text {, or in-person. The following boards have } \\
\text { temporarily waived criminal history background check and fee for licensure requirements, } \\
\text { among other requirements: State Board of Medical Examiners } \\
\text { - New Jersey will waive a host of regulatory requirements for healthcare professionals licensed } \\
\text { in other jurisdictions to become licensed in New Jersey and offer services to New Jersey }\end{array}$ & NJ DCA Guidance \\
\hline
\end{tabular}


residents, including telemedicine and telehealth services. The waivers will apply during the public health emergency related to COVID-19.

- Re: telehealth Reimbursement/Coverage Expansion: Increased access to telehealth under state Medicaid and direct third-party insurance administrators to inform beneficiaries about the availability of telemedicine and telehealth services.

- Re: controlled substances - An Administrative Order signed [August 11] by the Acting Director of the Division temporarily waives certain regulatory requirements for in-person medical evaluations when providers prescribe controlled dangerous substances ("CDS") in the treatment of chronic pain or authorize medical marijuana. It is effective immediately... The Order will remain in effect... [until] the end of the state of emergency or public health emergency...

- Re: continuity of care - On July 1, Gov. Murphy signed NJ S. 2467, which ensures that out-ofstate healthcare practitioners may continue to provide telemedicine to New Jersey residents until 90 days following the public health emergency.

- Re: telemedicine providers - The state's Division of Consumer Affairs last month adopted standards for telehealth use by audiologists, speech language pathologists, acupuncturists, physical therapists, psychologists, social workers, genetic counselors and nurses. The new rules will remain in effect for the duration of the COVID-19 public health emergency.

- $[1 / 7 / 22$ Update] re: interstate telemedicine - Any health care provider who uses telemedicine or engages in telehealth while providing health care services to a patient, shall: Be validly licensed, certified, or registered, pursuant to Title 45 of the Revised Statutes, to provide such services in the State of New Jersey... (NJ Statute C.45:1-62(2)(b)).

- [1/12/22 Update] re: EO 281 reinstituting waivers - "Authorizes individuals licensed in other states to practice in New Jersey without a New Jersey license. Allow health care providers licensed in other states to obtain New Jersey temporary licensure and provide services to New Jersey patients either through telemedicine or in-person."

- [1/20/22 Update] re: temporary emergency licensure - On January 12, 2022, Gov. Murphy signed S. 4139, which extends the temporary authorization to practice (including through telemedicine) for licensed, out-of-state health care professionals, as well as recently

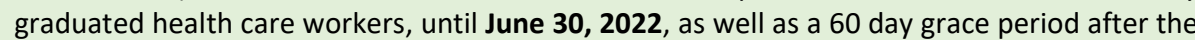
conclusion of the federal public health emergency.

- Status - Inactive, practitioners with temporary licenses expired August 31, 2022, when the NJ Division of Consumer Affairs discontinued the Temporary Emergency Reciprocity Licensure (TERL) Program, for all professions other than respiratory therapists.

- Further NJ DCA guidance: The Division continues to urge all TERL holders who wish to continue providing health care in the State of New Jersey after August 31, 2022 to apply for a plenary license in the State of New Jersey. To that end, the Division is authorizing a "bridge program" to plenary licensure available to all TERL holders. Any TERL holder who files a complete application for a plenary license in New Jersey (using the electronic application process available on the board websites) by 11:59 p.m. on August 31, 2022 will qualify for the "bridge program," and will be authorized to continue practicing in New Jersey under the TERL until the earliest of:

- The date of issuance of a New Jersey license;

- The date of notification of denial of an application for a plenary license in New Jersey; o The end of the day on March 31, 2023.

- New Mexico's order offers broad credentialing privileges: "The Department of Health and the Department of Homeland Security and Emergency Management shall credential out-ofstate professionals who can render aid and necessary services during the pendency of this order. NMSA 1978 §§ 12-10-10.1 through 12-10-13."

- NM Stat § 12-10-11: During an emergency, a person who holds a license, certificate or other permit that is issued by a state or territory of the United States and that evidences the meeting of qualifications for professional, mechanical or other skills may be credentialed, if appropriate and approved by the department of health or the homeland security and emergency management department, to render aid involving those skills to meet an emergency, subject to limitations and conditions as the governor may prescribe by executive order or otherwise.

- Use of electronic means (internet, texting, phone, email) to assess and provide responsible care during emergency will not be considered unethical or a violation of Medical Board rules.

- [6/29/21 Update] re: permanent interstate telemedicine - On April 6, 2021, Gov. Lujan Grisham signed SB 279 into law, which, among other things, states "The [Medical] board shall issue a licensed physician a telemedicine license to allow the practice of medicine across state lines to an applicant who holds a full and unrestricted license to practice medicine in another state or territory of the United States.
Temp. License Application

Telehealth Insurance Bulletin (3/10)

Press Release re: CDS

NJ S. 2467

Article re:

professions

EO 292 re: rescinded SoE

State Resource Page

Emergency

Declaration

NM Stat § 12-10-11

Instructions and

Application for

Temporary Licensure

NMMB Guidance re: Electronic Means

SB 279 (Interstate Telemedicine) 


\begin{tabular}{|c|c|c|}
\hline & $\begin{array}{l}\text { - Status - Inactive, Temporary licenses issued in June } 2020 \text { were active until July 1, } 2021 \text { per } \\
\text { Federal Emergency Licensure FAQs. However, SB } 279 \text { creates a process that allows physicians } \\
\text { licensed in other jurisdictions to provide services via telemedicine to New Mexico residents, } \\
\text { please see above for more information. } \\
\text { - Further, the Board of Osteopathic medicine offers a limited telemedicine license that allows } \\
\text { an osteopathic physician located outside New Mexico to practice osteopathic medicine on } \\
\text { patients located in New Mexico. The annual fee is } \$ 100 \text {. (NMAC 16.17.2.7 \& .8.) }\end{array}$ & $\underline{\text { State Resource Page }}$ \\
\hline New York & 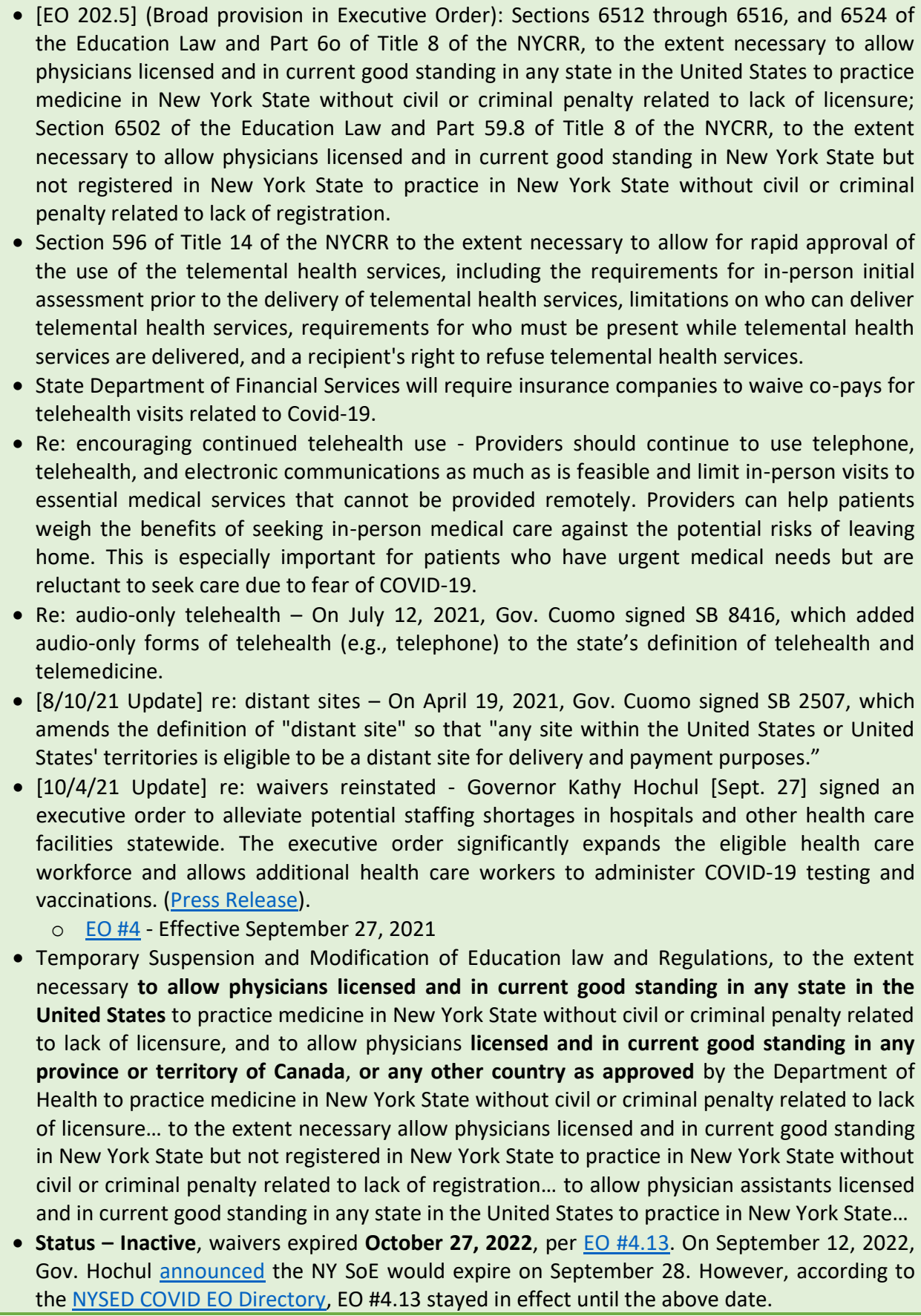 & $\begin{array}{l}\frac{\text { NYSED COVID EO }}{\text { Directory }} \\
\text { State Resource Page }\end{array}$ \\
\hline North Carolina & $\begin{array}{l}\text { - Any persons licensed in other states, territories, or the District of Columbia who are } \\
\text { providing healthcare services under the authority of the first paragraph of section } 16 \text { of } \\
\text { Executive Order No. } 116 \text { may continue to provide those services through April 15, 2020, } \\
\text { unless otherwise authorized by a professional healthcare licensure board under the authority } \\
\text { delegated in this Subsection... (2) Out-of-state licensees; telehealth. For the pendency of the } \\
\text { State of Emergency: (i) a health provider licensed, registered, or certified in good standing in } \\
\text { another United States jurisdiction (or reinstated pursuant to emergency action) may apply } \\
\text { for an emergency license with the appropriate North Carolina licensing board and, if deemed } \\
\text { eligible to be licensed, may deliver services in North Carolina, including through any remote } \\
\text { telecommunications technologies (telehealth), provided those services are within the }\end{array}$ & $\begin{array}{l}\frac{\text { Executive Order No. }}{130} \\
\frac{\text { Executive Order No. }}{116} \\
\frac{\text { Emergency Disaster }}{\text { License Application }} \\
\text { Article re: }\end{array}$ \\
\hline
\end{tabular}




\begin{tabular}{|c|c|c|}
\hline & $\begin{array}{l}\text { provider's authorized scope of practice in such other jurisdictions; and (ii) any restrictions } \\
\text { under North Carolina state law restricting the use of telehealth... have their enforcement } \\
\text { waived. } \\
\text { - In North Carolina, Blue Cross Blue Shield of North Carolina, the biggest insurance provider in } \\
\text { the state, announced March } 17 \text { it would cover virtual visits that occur over the phone, as well } \\
\text { as video, at the same rates as face-to-face visits. } \\
\text { - Status - Inactive, although North Carolina's state of emergency expired August 15, } 2022 \\
\text { (Source), there is a } 30 \text { day grace period, so emergency licenses expired September 14, } 2022 \text {. }\end{array}$ & $\begin{array}{l}\underline{\text { Reimbursement }} \\
\text { COVID-19 } \\
\underline{\text { Telemedicine FAQs }} \\
\underline{\text { State Resource Page }}\end{array}$ \\
\hline North Dakota & $\begin{array}{l}\text { - (North Dakota's order offers broad credentialing privileges) - The licensure requirements for } \\
\text { health care or behavioral health professionals licensed under the following Chapters of the } \\
\text { North Dakota Century Code are hereby suspended... Chapter } 43-17 \text { (Physicians and } \\
\text { Surgeons)... who are licensed and in good standing in other states, as needed to provide } \\
\text { health care and behavioral health services, to include telehealth care, for citizens impacted } \\
\text { by COVID-19, subject to identification, verification of credentials and other temporary } \\
\text { emergency requirements... certain statutory and regulatory requirements must be } \\
\text { suspended... b) the "audio-only" provision... c) insurance carriers shall cover virtual check-ins } \\
\text { and e-visits for established patients... } \\
\text { - } 3 / 9 / 22 \text { Update] re: reciprocal licenses - The board may also, in its discretion, enter into } \\
\text { reciprocal agreements with the licensing agencies of other states or territories or the District } \\
\text { of Columbia providing for a reciprocal waiver of further examination or any part thereof. (ND } \\
\text { CC } \S 43-17-21 \text { p. 8). } \\
\text { - Status - Inactive, the North Dakota state of emergency was rescinded on April 30, } 2021 \\
\text { (Article). EO 2021-09 rescinded prior Covid executive orders. However, North Dakota allows } \\
\text { reciprocal licensure, please see above. }\end{array}$ & $\frac{\text { Executive Order }}{\underline{2020-05.1}}$ \\
\hline $\begin{array}{l}\text { Northern } \\
\text { Mariana Islands }\end{array}$ & $\begin{array}{l}\text { - Existing CNMI law holds that "A physician licensed to practice in a foreign country other than } \\
\text { Canada may be granted a license to practice subject to the requirements and conditions } \\
\text { provided in regulations of the Board... (b) The Board shall provide regulation of the practice } \\
\text { of a regulated physician in the Commonwealth by a professional licensed to practice in a } \\
\text { foreign country with acceptable education, training, examination results and experience } \\
\text { comparable to that of a person who is otherwise qualified for licensure under this Chapter..." } \\
\text { (Health Care Professions Licensing Act of 2007). }\end{array}$ & $\begin{array}{l}\frac{\text { P.L. } 15-105 \text { Health }}{\text { Care Professions }} \\
\frac{\text { Licensing Act of } 2007}{\underline{\S 2214}} \\
\frac{\text { Territory Resource }}{\text { Page }}\end{array}$ \\
\hline Ohio & 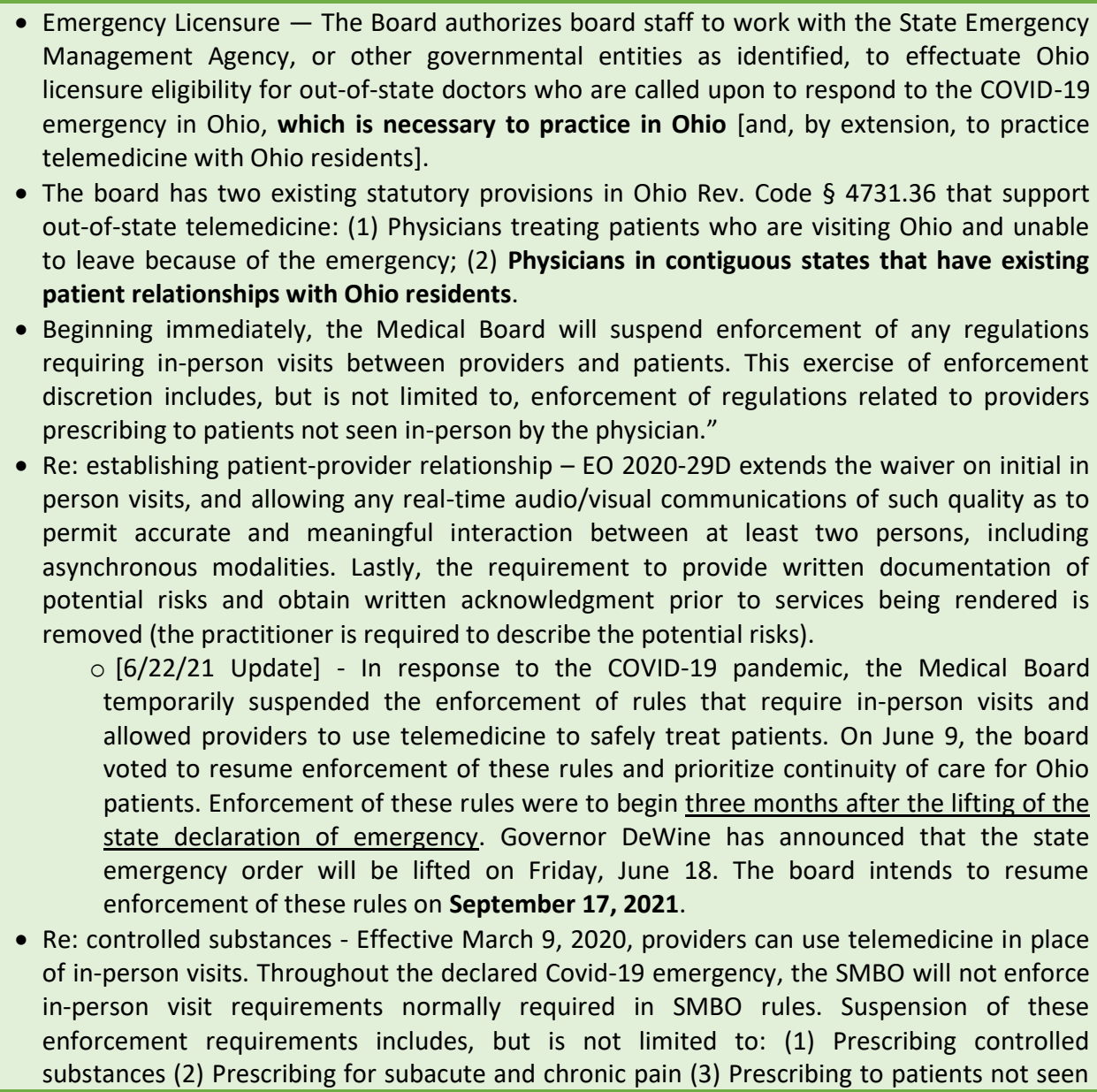 & $\begin{array}{l}\frac{\text { Ohio Rev. Code } \S}{\underline{4731.36}} \\
\frac{\text { Med Board }}{\text { Telemedicine }} \\
\text { Guidance }\end{array}$ \\
\hline
\end{tabular}


by the provider (4) Pain management (5) Medical marijuana recommendations and renewals (6) Office-based treatment for opioid addiction.

- Re: permanent changes to telehealth (Medicaid) - The rule changes to Ohio Administrative Code \$5160-1-18 include: Expanding the definition of telehealth to include telephone calls, remote patient monitoring and other electronic communication that does not have both audio and video elements... Fewer restrictions on patient and practitioner site locations... Expanding the types of telehealth services that may be paid for by Medicaid...

- [7/1/21 Update] re: reversing pandemic waivers: Ohio State Medical Board (OSMB) - On lune 17, the OSMB announced it would revert back to requirements for in-person visits and various telemedicine laws on September 17, 2021. OSMB will post more detail on these changes. (Article).

- [8/25/21 Update] re: pandemic waivers - At a June meeting, the Medical Board decided to resume enforcing the pre-pandemic telemedicine rules effective September 17, 2021, 90 days after the lifting of the state of emergency order. However, at a subsequent meeting on August 11, 2021, the Medical Board reconsidered and delayed the enforcement date to December 31, 2021. (Article).

- [11/11/21 Update] re: prescription drugs/medical marijuana - Ohioans will be able to continue using telemedicine through March 2022 for doctor visits that involve prescribing drugs or renewing medical marijuana cards. The State Medical Board on delayed the scheduled expiration of COVID-19 emergency rules [Dec. 31, 2021] that allow for more liberal use of telemedicine. The extended telemedicine rules will continue to lift in-person visitation requirements for: Prescribing controlled substances, Prescribing for subacute and chronic pain, Prescribing to patients not seen by the provider... Medical marijuana recommendations and renewals, Office-based treatment for opioid addiction. (Article).

- Ohio licensure required during the state of emergency - The Medical Board has received many inquiries regarding temporary licensure during the state emergency. Please be aware, Ohio law does not currently offer emergency or temporary licensure for out-of-state physicians. Unless an exemption applies (Ohio Revised Code 4731.36), physicians must hold an active Ohio license to practice medicine in the state of Ohio.

- Status - Ohio has no waivers for license reciprocity.

- Oklahoma's order offers broad credentialing privileges: "Any medical professional who holds a license, certificate, or other permit issued by any state that is a party to the Emergency Management Compact evidencing the meeting of qualifications for the practice of certain medical services... shall be deemed license to practice in Oklahoma so long as this order is in effect... b) Any medical professional intending to practice in Oklahoma... must receive approval from appropriate Board; c) It is the responsibility of each Board to verify the license status of any applicant. All occupational licenses... shall be extended so long as this Order is in effect."

- Telemedicine and Telehealth (a) To the extent not already allowed by applicable law, licensed medical doctors, surgeons, and physician assistants may utilize telemedicine or telehealth to provide care for new or existing patients. (b) Subsection (a) shall not be construed to allow licensed medical doctors, surgeons, or physician assistants to prescribe opiates and other controlled dangerous substances COVID - 19 Emergency Rules Adopted by the Oklahoma Medical Board in its Virtual Special Meeting on April 14, 2020 Page 4 of 4 without a preexisting physician-patient relationship...

- Re: establishing relationship - Gov. Stitt's order also waives part of Oklahoma state law requiring an existing doctor-patient relationship before telemedicine consultations can be conducted.

- Re: controlled substances - [5 $5^{\text {th }}$ Amended EO 2020-20] Telemedicine shall be used to maximum potential and shall be allowed for non-established patients... The preexisting patient relationship requirement for telemedicine... only applies to the prescribing of opiates and other controlled substances...

- [8/25/21 Update] re: reinstituting waivers - The Oklahoma Board of Medical Licensure and Supervision and the State Board of Osteopathic Examiners recently passed emergency rules to fast-track temporary, "critical need" licenses for physicians and other medical professionals. The rules approved by Gov. Kevin Stitt allow inactive or out-of-state doctors, respiratory therapists and physician assistants in good standing to quickly qualify for a temporary license to be able to get to work... The temporary licenses aren't reserved solely for physicians treating COVID-19 patients, said Board of Osteopathic Examiners Executive Director Michael Leake Jr. (Article).

- [1/11/22 Update] re: interstate telehealth - Physician treating patients in OK through telemedicine must be fully licensed in OK. (OK Ad. Code $\S 435: 10-7-13(a)$ ). The State Board of Osteopathic Examiners has the authority to issue a telemedicine license. (OK Stat., Tit. 59, $\S$
Article re: Permanent

Medicaid changes

OMB Newsletter (re:

No license

reciprocity)

Article re: Reversing waivers

OMB Telemedicine FAQs 8/11/21

$\underline{\text { State Resource Page }}$

Amended Executive Order 2020-07

COVID-19 Pandemic Emergency Rules

Article re: Preexisting Relationship

[MDs]: Application for Emergency Licensure

[DOs]: Emergency Temporary License Application

EO 2021-11

State Resource Page 


\begin{tabular}{|c|c|c|}
\hline & 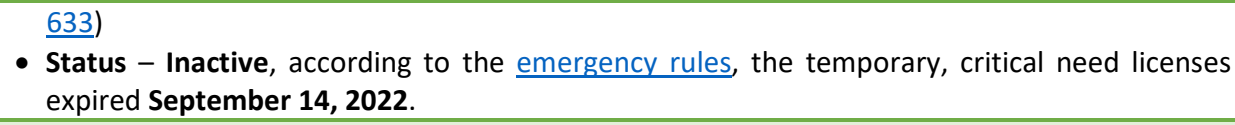 & \\
\hline Oregon & $\begin{array}{l}\text { - [Board of Med Guidance] - Physicians and PAs with an active status license to practice } \\
\text { medicine in Oregon may provide care via telemedicine to their Oregon patients. Out-of-state } \\
\text { physicians with a telemedicine license may provide remote care to their Oregon patients. } \\
\text { - Re: controlled substances - Out-of-state Licensees who hold an active license at telemedicine } \\
\text { status have the same duties and responsibilities and are subject to the same penalties and } \\
\text { sanctions as any other licensed physician in Oregon. Physicians with telemedicine status in } \\
\text { Oregon may not act as a dispensing physician, treat a patient for intractable pain, act as a } \\
\text { supervising physician of a licensed physician assistant or an Oregon-certified First Responder } \\
\text { or Emergency Medical Technician. } \\
\text { - [9/8/21 Update] re: Out-of-state license - Upon application, the Oregon Medical Board may } \\
\text { issue to an out-of-state physician a license for the practice of medicine across state lines if } \\
\text { the physician holds a full, unrestricted license to practice medicine in any other state of the } \\
\text { United States, has not been the recipient of a professional sanction by any other state of the } \\
\text { United States and otherwise meets the standards for Oregon licensure under this chapter... } \\
\text { (4) A license for the practice of medicine across state lines is not a limited license... (5) A } \\
\text { license for the practice of medicine across state lines does not permit a physician to practice } \\
\text { medicine in this state... (ORS } 677.139 \text { ). } \\
\text { - [12/23/21 Update] re: State of Emergency reinstated - Similarly, having the emergency } \\
\text { declaration in place has allowed state licensing boards greater flexibility around professional } \\
\text { health licensing, ensuring that we have as much flexibility with our healthcare workers as } \\
\text { possible. [EO 21-36]. } \\
\text { - Status - Inactive, the Oregon State of Emergency was rescinded April 1, 2022. (Article). }\end{array}$ & $\frac{\text { ORS } 677.139 \text { re: OOS }}{\text { License }}$ \\
\hline Pennsylvania & 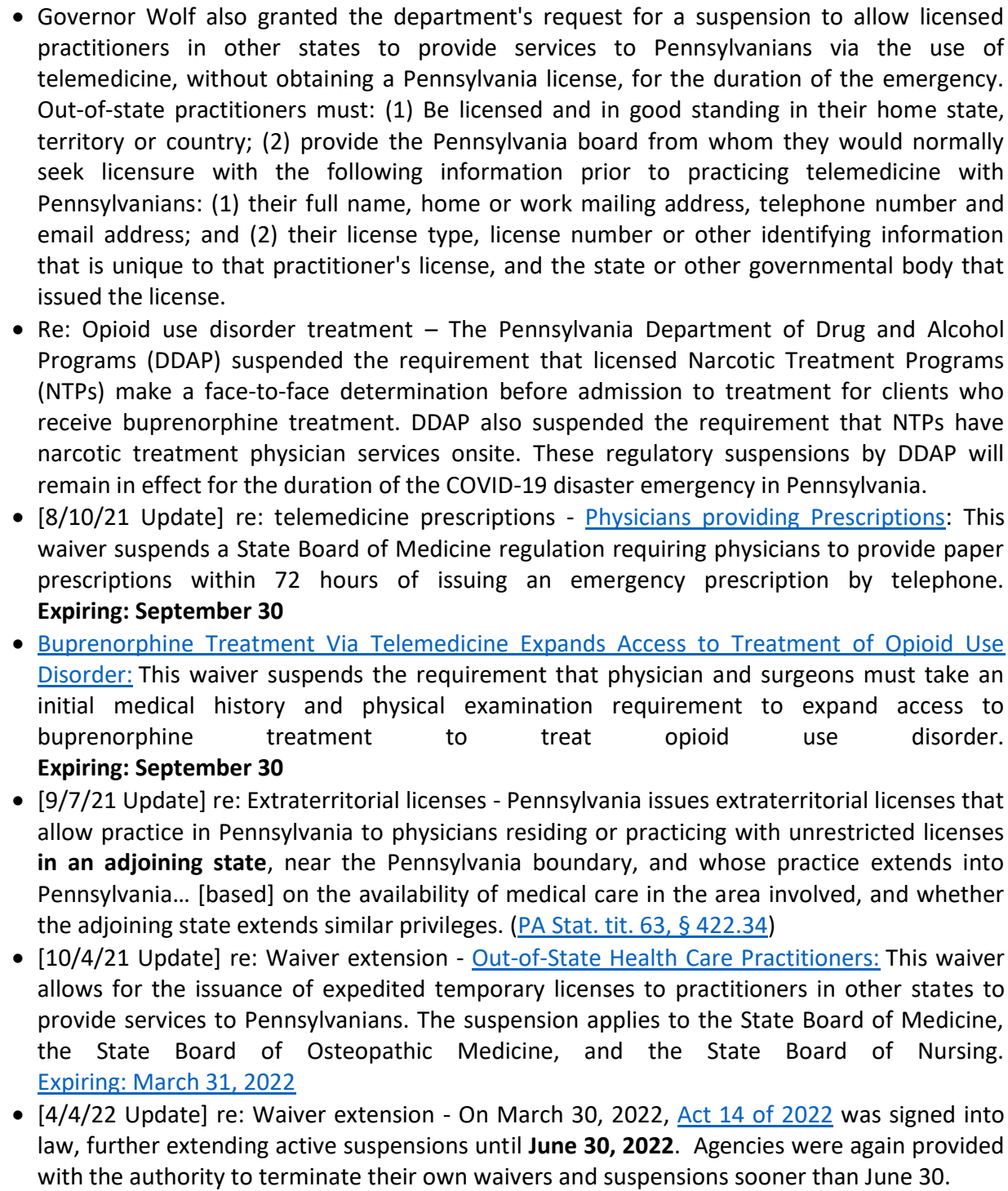 & $\frac{\text { PA Stat. tit. } 63, \S}{\underline{422.34 \text { re: }}}$ \\
\hline
\end{tabular}




\begin{tabular}{|c|c|c|}
\hline & 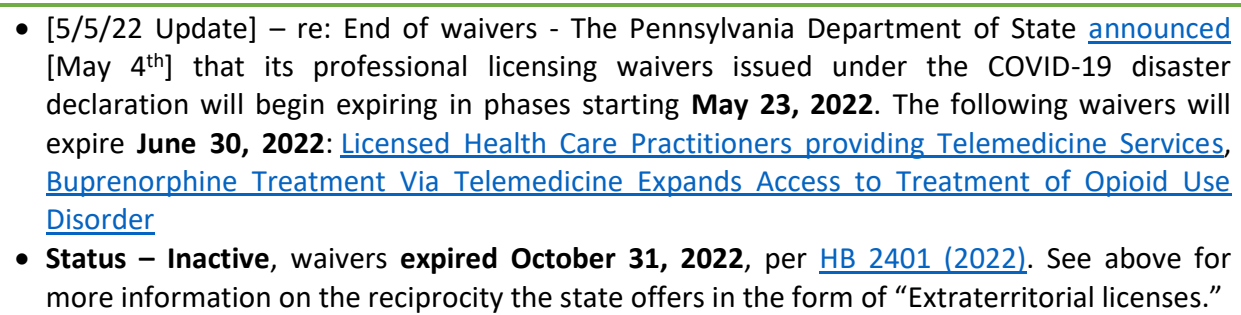 & \\
\hline$\underline{\text { Puerto Rico }}$ & $\begin{array}{l}\text { - Existing PR law provides for broad discretion during emergencies: "The Board may grant a } \\
\text { provisional license to any physician who legally practices medicine in other state[s] or } \\
\text { jurisdiction[s], contingent upon the request by the physician to the Board and on condition } \\
\text { that the physician comes to the Commonwealth of Puerto Rico to assist in emergency } \\
\text { services during a disaster, as authorized by the Department of Justice. The Department of } \\
\text { Health shall approve regulations to such effect... (4) The Board may grant a provisional } \\
\text { license to any physician who legally practices medicine at a state or jurisdiction, with the } \\
\text { purpose of having said physician render gratis and volunteer medical services or assistance in } \\
\text { Puerto Rico during a period of time that is not to exceed ninety (90) days a year as of its date } \\
\text { of issue. Provided, that this license shall be granted without paying any fees... (4) The Board } \\
\text { may grant a provisional license to any physician who legally practices medicine at a state or } \\
\text { jurisdiction, with the purpose of having said physician render gratis and volunteer medical } \\
\text { services or assistance in Puerto Rico during a period of time that is not to exceed ninety (90) } \\
\text { days a year as of its date of issue. Provided, that this license shall be granted without paying } \\
\text { any fees." (P.R. Laws tit. } 20, \S 133 g \text { ) } \\
\text { - On March 20, 2020, the Governor of Puerto Rico signed Joint Senate Resolution } 491, \text { which } \\
\text { provides the flexibility for physicians who are authorized to practice in Puerto Rico to use } \\
\text { telemedicine and telephone medical consultations as a remote means to care for patients, } \\
\text { regardless of whether or not they have telemedicine certification issued by the Medical } \\
\text { Licensure and Discipline Board. Under the Joint Resolution, in its relevant part, it is provided } \\
\text { that individuals who are authorized to practice the profession in Puerto Rico may invoice for } \\
\text { services rendered through telemedicine, telephone consultations, or by any other authorized } \\
\text { method, and the health insurers and health service organizations shall have the obligation to } \\
\text { pay for such as if it were an in-person consultation for the health services rendered. } \\
\text { - Status - N/A. However, }\end{array}$ & $\frac{\text { P.R. Laws tit. } 20, \S}{\underline{133 \mathrm{~g}}}$ \\
\hline Rhode Island & $\begin{array}{l}\text { - The Board wishes to make clear that it encourages all physicians to use telemedicine to } \\
\text { deliver care to their patients and that the Board will not take action against physicians not } \\
\text { licensed to practice in Rhode Island who, during the state of emergency, use telemedicine to } \\
\text { deliver care to their established Rhode Island patients. The patient location requirement for } \\
\text { telemedicine contained in Rhode Island General Laws } \S 27-81-3 \text { (9) is hereby suspended. } \\
\text { Patients may receive telemedicine services at any location. The prohibition against audio- } \\
\text { only telephone conversation and the limitations on video conferencing... is hereby } \\
\text { suspended. All such clinically appropriate, medically necessary telemedicine services } \\
\text { delivered by in-network providers shall be reimbursed at rates not lower than services } \\
\text { delivered through traditional (in-person) methods. } \\
\text { - [1/21/21 Update] - If you are providing telehealth services to a patient who lives in Rhode } \\
\text { Island and you wish to continue providing treatment you must apply for a full Rhode Island } \\
\text { license or the patient must obtain treatment from a provider who holds an active Rhode } \\
\text { Island license. } \\
\text { - Re: insurance - Health insurers must cover telemedicine for primary care, specialty care and } \\
\text { mental and behavioral health care. } \\
\text { - [6/22/21 Update] - If you are providing telehealth services to a patient who lives in Rhode } \\
\text { Island and you wish to continue providing treatment you must apply for a full Rhode Island } \\
\text { license or the patient must obtain treatment from a provider who holds an active Rhode } \\
\text { Island license. } \\
\text { - [7/19/21 Update] EO } 20-06 \text { terminated - On July } 6,2021, \text { EO } 20-06 \text { (Fourth Supplemental } \\
\text { Emergency Declaration - Expanding Access to Telemedicine Services) was rescinded per EO } \\
21-76 \text {. } \\
\text { - } 1 / 11 / 22 \text { Update] re: interstate telemedicine - RI allows physicians who have a license in } \\
\text { good standing in another state to consult with RI licensed physician on a singular occasion or } \\
\text { provide teaching assistance for no more than seven days unless extended with written } \\
\text { permission from the director. (RI Gen. Law, } \S 5-37-16.2 \text { (a)(3)). } \\
\text { established patients, was rescinded by EO } 21-76 \text {. }\end{array}$ & $\frac{\text { Executive Order 20- }}{\frac{06 \text { re: Expanded }}{\underline{\text { Telemedicine }}}}$ \\
\hline South Carolina & - The South Carolina Board of Medical Examiners is temporarily waiving South Carolina & Article re: OOS \\
\hline
\end{tabular}




\begin{tabular}{|c|c|c|}
\hline & $\begin{array}{l}\text { licensing requirements for physicians, physician assistants, and respiratory care practitioners } \\
\text { licensed and in good standing in another state and whose services are determined to be } \\
\text { necessary by the South Carolina Department of Health and Environmental Control (DHEC). } \\
\text { The Board has indicated that this means South Carolina will permit these categories of out- } \\
\text { of-state practitioners to treat South Carolina residents, in person or through telehealth } \\
\text { technologies, to screen or treat patients for the coronavirus. The scope of permitted } \\
\text { practice and treatment by these practitioners may expand during the course of the } \\
\text { coronavirus emergency, subject to additional agency input. } \\
\text { - Re: controlled substances - The Board hereby suspends enforcement of the prohibition on } \\
\text { prescribing Schedule II and III medications via telemedicine without prior Board approval, } \\
\text { subject to certain conditions. Such approval is granted to the following practitioners who are } \\
\text { permanently licensed in good standing in South Carolina and physically present in South } \\
\text { Carolina at the time care is provided... the Board will enforce all other aspects of the } \\
\text { Telemedicine Act... including the practitioner's participation in the South Carolina } \\
\text { Prescription Monitoring Program... and the prohibition on prescribing all other classes of } \\
\text { drugs. } \\
\text { - Re: medication-assisted treatment - Practitioners previously approved by the Board may, in } \\
\text { accordance with state and federal law, initiate MAT treatment for patients diagnosed with } \\
\text { an opioid use disorder via telemedicine, without the need for an in-person visit, provided } \\
\text { that the initiation of MAT is documented in the patient's chart and the practitioner sees the } \\
\text { patient in-person within sixty) days after the end of the public health state of emergency. } \\
\text { - [1/11/22 Update] re: interstate telemedicine - The physician must be licensed in South } \\
\text { Carolina; however, they do not need to reside in South Carolina. (SC Code Ann. } \S 40-47- \\
\text { 37(C)(9)). } \\
\text { Status - Inactive, the state's emergency declaration expired June } 6,2021 \text {, per EO 2021-25. } \\
\text { (Article). }\end{array}$ & $\frac{\text { EO 2020-BME-PH-03 }}{\frac{\text { re: controlled }}{\text { substances }}}$ \\
\hline South Dakota & 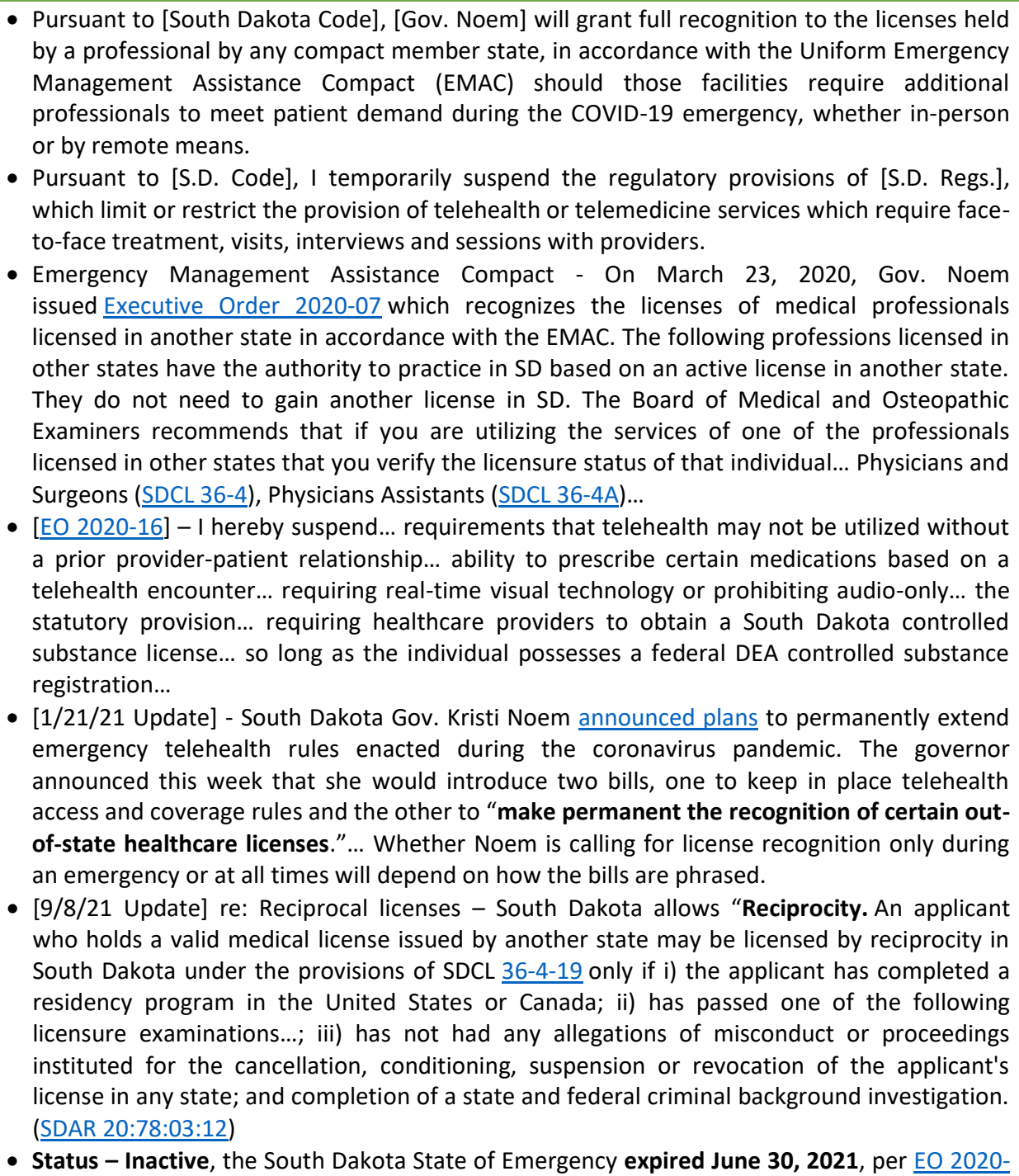 & $\frac{\text { Article re: Permanent }}{\underline{\text { changes }}}$ \\
\hline
\end{tabular}




\begin{tabular}{|c|c|c|}
\hline & $\begin{array}{l}34 \text { and was not renewed. However, South Dakota does offer a reciprocal license, see above } \\
\text { for more information. }\end{array}$ & \\
\hline Tennessee & 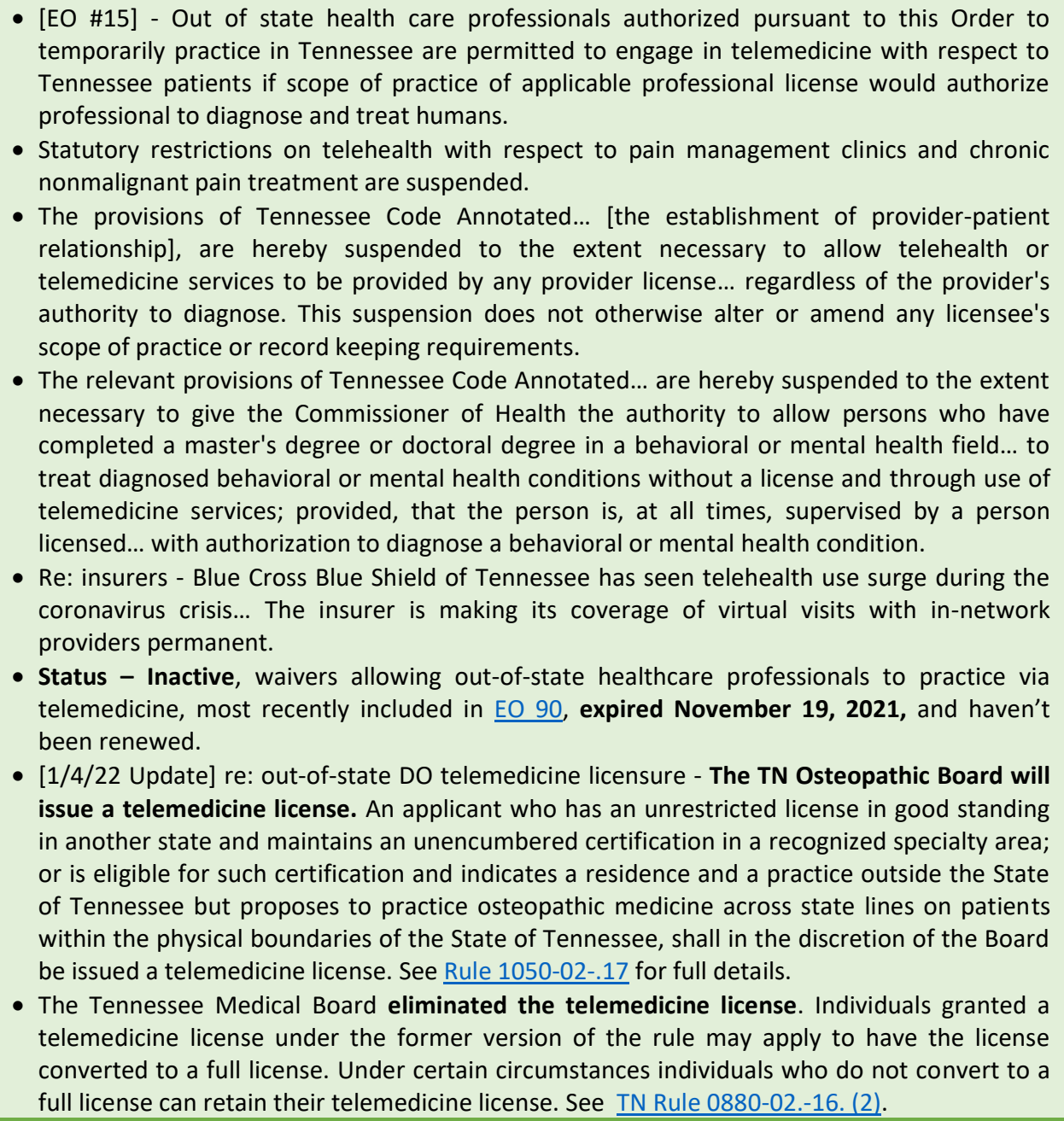 & $\begin{array}{l}\frac{\text { Tenn. Rule 1050-02- }}{\frac{.17 \text { (DO }}{\text { Telemedicine) }}} \\
\text { TN Executive Orders }\end{array}$ \\
\hline Texas & 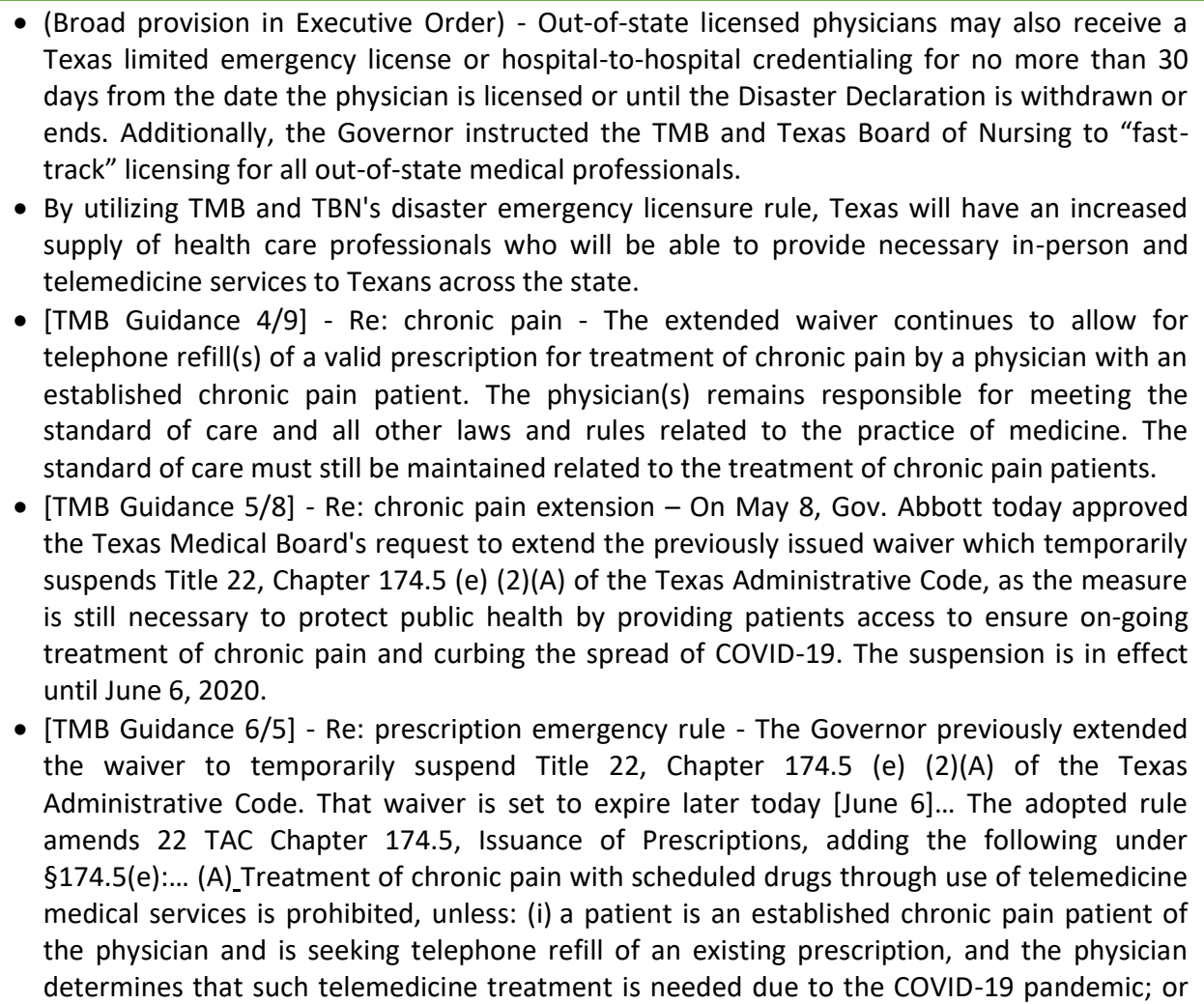 & TMB Guidance 4/9 \\
\hline
\end{tabular}




\begin{tabular}{|c|c|c|}
\hline & 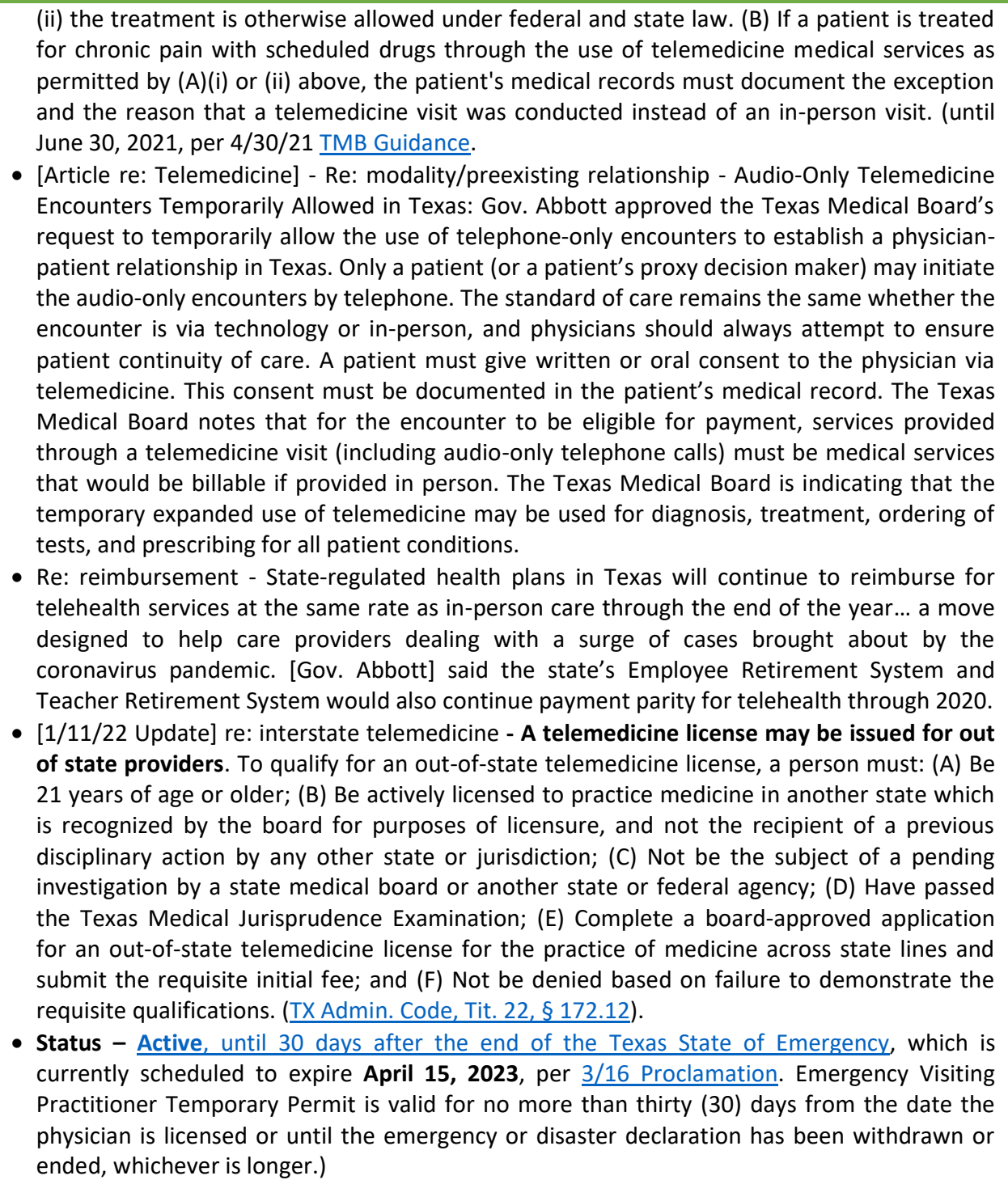 & $\begin{array}{c}\text { Article re: } \\
\text { Reimbursement }\end{array}$ \\
\hline Utah & $\begin{array}{l}\text { - Utah law provides: "An out-of-state physician may practice without a Utah license if: (1) } \\
\text { The physician is licensed in another state, with no licensing action pending and at least } 10 \\
\text { years of professional experience; (2) The services are rendered as a public service and for a } \\
\text { noncommercial purpose; (3) No fee or other consideration of value is charged, expected or } \\
\text { contemplated, beyond an amount necessary to cover the proportionate cost of malpractice } \\
\text { insurance; (4) The physician does not otherwise engage in unlawful or unprofessional } \\
\text { conduct." (UT Code Ann. §58-67-305(7)). } \\
\text { - A medical provider that pursuant to this Order offers telehealth services that do not comply } \\
\text { with HIPAA or HITECH, so long as the provider: (1) inform the patient the telehealth service } \\
\text { does not comply with those federal acts; (2) give the patient an opportunity to decline use of } \\
\text { the telehealth service; and (3) take reasonable care to ensure security and privacy of the } \\
\text { telehealth service. } \\
\text { - [EO 2020-68] Continues the suspension of certain aspects of the Utah Telehealth Act, } \\
\text { including allowing HIPAA exceptions (with proper notice). } \\
\text { - Status - Inactive, Utah's State of Emergency expired June 1, 2021, according to the National } \\
\text { Academy for State Health Policy (NASHP); the state's licensing waiver persisted much longer, } \\
\text { as of April 21, 2022, Utah's Division of Occupational and Professional Licensing (DOPL) is no } \\
\text { longer listing emergency, out-of-state licenses. However, Utah does offer limited, pro bono } \\
\text { interstate telemedicine, please see above. }\end{array}$ & $\begin{array}{l}\frac{\text { UT Code Ann. § 58- }}{\frac{\text { 67-305(7) re: }}{\frac{\text { Interstate }}{\text { telemedicine }}}} \\
\frac{\text { DOPL COVID }}{\underline{\text { Resources }}} \\
\underline{\text { EO 2020-07 }} \\
\underline{\text { EO 2020-68 }} \\
\text { DOH Orders and } \\
\text { Directives } \\
\text { State Resource Page }\end{array}$ \\
\hline $\begin{array}{l}\frac{\text { Vermont }}{\text { (osteopathic }} \\
\text { only) }\end{array}$ & $\begin{array}{l}\text { - Special provisions for the COVID-19 public health emergency have been passed to facilitate } \\
\text { practice in Vermont by healthcare professionals who are not licensed in Vermont. This sets } \\
\text { forth information for physicians (MD), physician assistants, and podiatrists. There are two } \\
\text { different paths available to be able to practice during the emergency, "deemed" and } \\
\text { "emergency", both are expedited and free. } \\
\text { - MDs, physician assistants, and podiatrists who meet all the criteria below can be deemed to }\end{array}$ & Med Board Guidance \\
\hline
\end{tabular}




\begin{tabular}{|c|c|c|}
\hline & 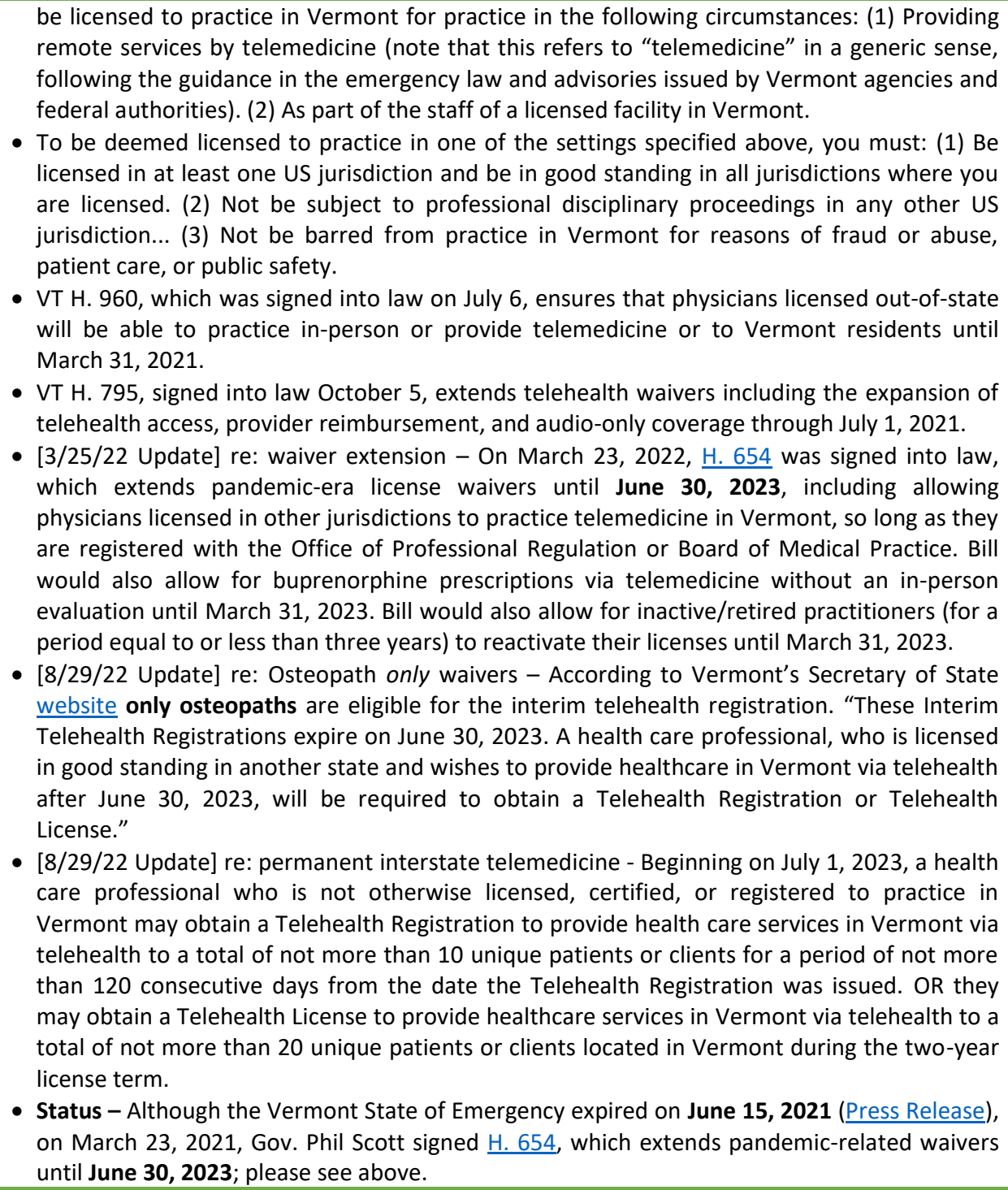 & $\begin{array}{l}\frac{\text { VT SOS Guidance: }}{\text { Telehealth, Out-of- }} \\
\text { State \& Expired } \\
\text { License Registration }\end{array}$ \\
\hline$\frac{\text { U.S. Virgin }}{\underline{\text { Islands }}}$ & $\begin{array}{l}\text { - Pending legislation states, in part "A physician or health care provider not licensed in this } \\
\text { Territory may provide health care services to a patient located in this Territory using } \\
\text { telehealth if the heath care professional registers with the applicable Board, or the } \\
\text { Department if there is no Board, and provides health care services within the applicable } \\
\text { scope of practice... if the health care provider (A) Completes an application... (B) Is licensed } \\
\text { with an active, unencumbered license that is issued by another state, the District of } \\
\text { Columbia... (C) Has not been subject of disciplinary action... during the 5-year period } \\
\text { immediately prior..." }\end{array}$ & $\begin{array}{l}\begin{array}{c}\text { Virgin Islands } \\
\text { Telehealth Act }\end{array} \\
\frac{\text { Territory Resource }}{\underline{\text { Page }}}\end{array}$ \\
\hline Virginia & $\begin{array}{l}\text { - [Board Brief \#91] - Governor Northam's Executive Order } 57 \text { allowed practice by out-of-state } \\
\text { health care professionals and expanded authority for physician assistants, nurse } \\
\text { practitioners, interns/residents/fellows/senior medical students... } \\
\text { - Virginia's order offers broad credentialing privileges: "During the state of emergency } \\
\text { declared in Amended Executive Order 51, a license issued to a health care practitioner by } \\
\text { another state, and in good standing with such state, shall be deemed to be an active license } \\
\text { issued by the Commonwealth to provide health care or professional services as a health care } \\
\text { practitioner of the same type for which such license is issued in another state, provided such } \\
\text { health care practitioner is engaged by a hospital, or an affiliate of such hospital where both } \\
\text { share the same corporate parent, licensed nursing facility, or dialysis facility in the } \\
\text { Commonwealth for the purpose of assisting that facility with public health and medical } \\
\text { disaster response operations." } \\
\text { - COVID-19 Expedited Licensure: During the declared coronavirus emergency in Virginia, the } \\
\text { board of medicine is streamlining its licensing process for the following professions: medicine } \\
\text { and surgery, osteopathic medicine and surgery, physician assistant... in addition, the Board } \\
\text { already has an expedited licensure by endorsement process for medicine and } \\
\text { osteopathy applicants who: 1) Have practiced in another state for } 5 \text { years, 2) Are board }\end{array}$ & $\frac{\text { Board of Medicine }}{\text { Guidance }}$ \\
\hline
\end{tabular}


certified.

- [EO 57] - Health care practitioners with an active license issued by another state may provide continuity of care to their current patients who are Virginia residents through telehealth services. Establishment of a relationship with a new patient requires a Virginia license unless pursuant to [the paragraph above].

- Re: adjoining state licensing exceptions - [According to] Va. Code Ann. § 54.1-2901(A), the requirement that a physician be licensed in the state of Virginia before providing clinical services to a patient located in Virginia does not apply to the rendering of medical advice or information through telecommunications from a physician licensed to practice medicine in Virginia or an adjoining state.

- Re: modality - A healthcare practitioner may use any non-public facing audio or remote communication product that is available to communicate with patients. This exercise of discretion applies to telehealth provided for any reason regardless of whether the telehealth service is related to the diagnosis and treatment of COVID-19.

- Re: originating site - Virginia Governor Ralph Northam has signed legislation (HB 5046/SB 5080) that amends the Commonwealth's telehealth laws to eliminate originating site restrictions and the requirement that the patient be accompanied by a care provider during the telehealth session... The bill expands the telehealth platform to allow care providers to treat patients in their own homes or other locations, including businesses, schools and clinics. It also mandates that payers cover telehealth services regardless of the originating site and whether a provider is with the patient and directs the state Medicaid program to continue covering audio-only phone services.

- [1/11/22 Update] re: interstate telemedicine - To practice telemedicine into Virginia requires a license from the Board of Medicine. The Board notes that $\S 38.2-3418.16$ states "Telemedicine services" does not include an audio-only telephone, electronic mail message, facsimile transmission, or online questionnaire. The Board believes that these communications do not constitute telemedicine, and therefore do not require licensure, when used in the follow-up care of a Virginia resident with whom a bona fide practitionerpatient relationship has been previously established. (VA BOM Telemedicine Guidelines $\underline{6 / 24 / 21})$.

- $[1 / 19 / 22$ Update] re: reactivating waivers - "Healthcare workers across the country are facing severe burnout and exhaustion 22 months into the pandemic. Reinstituting both the authorization of out-of-state licensed professionals to provide care to the citizens of the Commonwealth and the availability of telehealth services will assist in meeting that demand..." [EO 84, 1/10/22].

- Status - Inactive, Virginia's state of emergency expired March 22, 2022, per EO 16, and hasn't been renewed.

- Washington offers broad credentialing privileges: "If volunteers are registered in the volunteer health practitioner system and verified to be in good standing in all states where they are licensed, they may practice in Washington without obtaining a Washington license once activated and assigned by $\mathrm{DOH}$... Out-of-state practitioners may: (1) Become volunteers via RCW $\S 70.15$ by registering and completing the Emergency Volunteer Health Practitioners Application; (2) Out of state MDs and DOs that would like an expedited Washington license and to volunteer, may use the Interstate Medical License Compact and become registered under RCW § 70.15.

- RCW § 70.15.050: “(1) While an emergency declaration is in effect, a volunteer health practitioner, registered with a registration system that complies with RCW 70.15.040 and licensed and in good standing in the state upon which the practitioner's registration is based, may practice in this state to the extent authorized by this chapter as if the practitioner were licensed in this state..."

Washington - [Proc. 20-29] - Re: payment parity - I also prohibit the following activities by health carriers to encourage... telemedicine services by providing for payment parity between telemedicine and in-person medical services: (1) Reimbursing in-network providers for telemedicine claims for medically necessary covered services at a rate lower than the contracted rate that would be paid if the services had been delivered through traditional (in-person) methods. (2) Denying a telemedicine claim from an in-network provider for a medically necessary covered service due to an existing provider contract term with that provider that denies reimbursement for services provided through telemedicine. (3) Establishing requirements for the payment of telemedicine services that are inconsistent with the emergency orders, rules or technical advisories to carriers issued by the Office of the Insurance Commissioner.

- Re: establishing relationship - New administrative code rule, WAC 182-551-2040, allows face-to-face requirements for home health care to be met using telemedicine or telehealth services (makes permanent a COVID-19 emergency rule).

Medical Commission Guidance

Emergency Volunteer Health Practitioners Application

$\underline{\mathrm{RCW}} \S 70.15 .050$

Emergency Proclamation 20-29

WA SSB 5423 (2021) I SSB 5423 Bill Summary (re: consultation exemption) 


\begin{tabular}{|c|c|c|}
\hline & 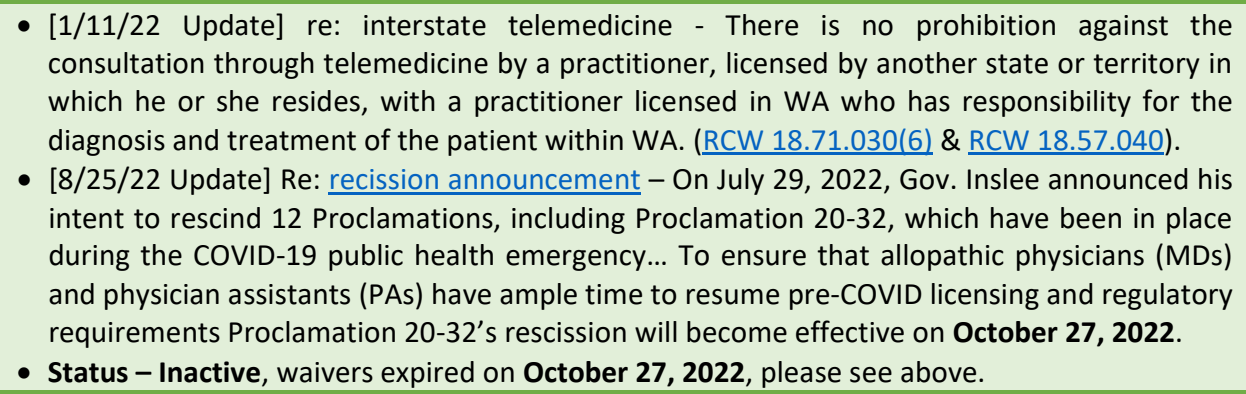 & $\frac{\text { WMC announcement }}{\underline{\text { re: waiver recission }}}$ \\
\hline Washington, DC & 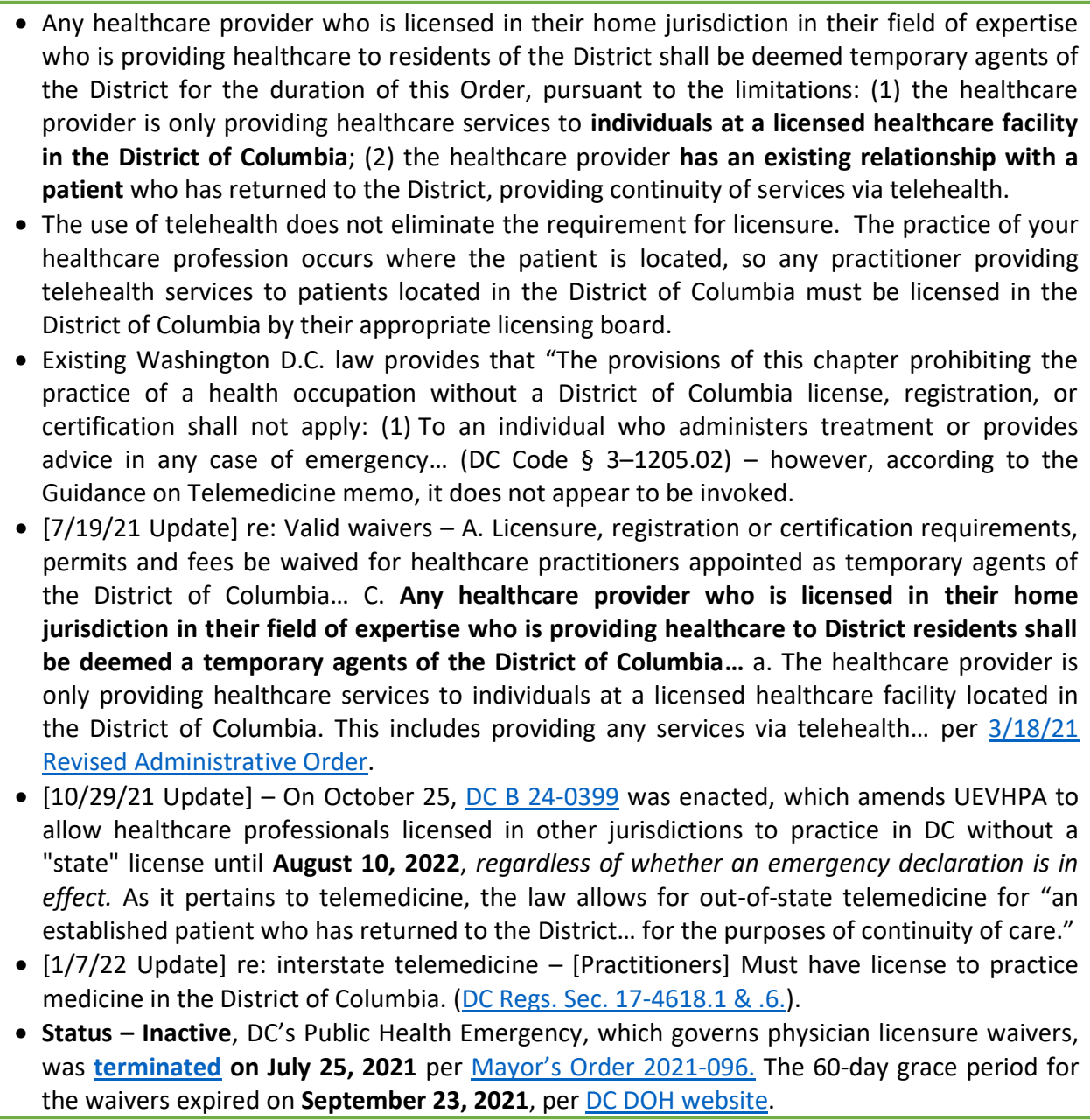 & $\frac{3 / 18 / 21 \text { Revised }}{\text { Administrative Order }}$ \\
\hline West Virginia & $\begin{array}{l}\text { - The following statutory regulations are to be suspended for the duration of the State of } \\
\text { Emergency: Requirement for telemedicine providers to be licensed in West Virginia... } \\
\text { provided that such provider possess a license within their own state... requirement that } \\
\text { telemedicine be performed by video only. } \\
\text { - West Virginia has expanded the use of audio-visual telehealth for non-emergent E\&M } \\
\text { services to Medicaid members, for mental health visits and in federally qualified health } \\
\text { centers (FQHCs) and rural health clinics (RHCs). } \\
\text { - [WV BOM Fall } 2020 \text { Newsletter] Re: preexisting relationships/audio-only } \\
\text { modalities/reimbursements - For the duration of the COVID-19 emergency, the prohibition } \\
\text { on establishing a provider-patient relationship via audio-only communication is suspended } \\
\text { temporarily. If audio-only communication satisfies the standard of care for a particular } \\
\text { patient presentation, it may be used to establish a provider-patient relationship and to } \\
\text { provide patient care. Effective March } 1 \text {, the U.S. Department of Health and Human Services } \\
\text { and Centers for Medicare \& Medicaid Services increased telehealth reimbursements to equal } \\
\text { other audiovisual and in-person visitation reimbursements. } \\
\text { - } 6 / 22 / 21 \text { Update] WV HB } 2024 \text {, which was signed into law on May } 20,2021 \text {, allows health } \\
\text { care practitioners licensed and in good standing in another jurisdiction to pay a fee to } \\
\text { become registered with the appropriate medical board (allopathic or osteopathic) and } \\
\text { become an "interstate telehealth practitioner" and practice medicine with West Virginia } \\
\text { patients. West Virginia holds jurisdictional authority, but the registrant has the responsibility }\end{array}$ & $\begin{array}{l}\frac{\text { Article re: Audio-only }}{\text { telehealth }} \\
\frac{\text { WV BOM Fall 2020 }}{\underline{\text { Newsletter }}} \\
\text { WV HB 2024 }\end{array}$ \\
\hline
\end{tabular}




\begin{tabular}{|c|c|c|}
\hline & $\begin{array}{l}\text { to report any restrictions placed on their license in other jurisdictions to WV boards. } \\
\text { - } 99 / 9 / 22 \text { Update] re: Emergency waivers - According to WVBOM guidance, eligible physicians } \\
\text { and physician assistants may register with the Board to practice in West Virginia during the } \\
\text { COVID-19 State of Emergency. Providers are only eligible for one emergency registration, } \\
\text { which are valid for a period of sixty days or five business days after the declared state of } \\
\text { emergency terminates, whichever is sooner. } \\
\text { - }[12 / 1 / 22 \text { Update] re: end of SoE - On November } 30,2022 \text {, West Virginia Gov. Jim Justice said } \\
\text { that the state's COVID state of emergency would be allowed to expire on January } 1, \mathbf{2 0 2 3} \text {. } \\
\text { The SoE has been in effect since March } 16,2020 \text {, and allows for a series of waivers, including } \\
\text { allowing out-of-state physicians to practice in person and via telemedicine, and expediting } \\
\text { the licensure of inactive and retired physicians. } \\
\text { - Status - Inactive, West Virginia's State of Emergency expired on January } 1, \mathbf{2 0 2 3} \text {. Please see } \\
\text { above for more information. Additionally, West Virginia offers interstate telemedicine } \\
\text { registration, please see the } 6 / 22 / 21 \text { update above. }\end{array}$ & $\frac{\text { Emergency Order 1- }}{\underline{22 \text { (ending SoE) }}}$ \\
\hline Wisconsin & $\begin{array}{l}\text { - [EO 16] - III. Telemedicine. A. The following is ordered as it relates to telemedicine for } \\
\text { Wisconsin residents: } 1 \text { ) A physician providing telemedicine in the diagnosis and treatment of } \\
\text { a patient located in this state must have a valid and current license issued by this State, } \\
\text { another state, or Canada... 2) A physician practicing under this section cannot be currently } \\
\text { under investigation and must not currently have any restrictions or limitations placed on } \\
\text { their license by their credentialing state or any other jurisdiction. } \\
\text { - Re: recission of waivers - [Em. O } 16 ; 3 / 27 / 20] \text { This Order is effective immediately and shall } \\
\text { remain in effect for the duration of the public health emergency as declared in Executive } \\
\text { Order \#72 [3/12/20], including any extensions. On May } 11,2020 \text {, EO } 72 \text { expired and was } \\
\text { replaced by EO } 82, \text { which did not adopt EOs \#16 \& \#20 (a modification of EO 16) and thus an } \\
\text { out-of-state practitioner is not able to work in Wisconsin through Interstate Reciprocity. } \\
\text { - [Wisconsin DSPS Memo] - The legislature did not extend the public health emergency and it } \\
\text { ended May } 11,2020 . \text { Therefore, your temporary license will expire on June } 10,2020 \text {. This } \\
\text { temporary license cannot be renewed. } \\
\text { - [October } 1,2020 \text { Update] - [The October } 1 \text { ] order provides for temporary interstate license } \\
\text { reciprocity for healthcare providers to work in Wisconsin healthcare facilities, extends } \\
\text { licenses that may expire during the federal emergency declaration for } 30 \text { days after its } \\
\text { conclusion, and makes it easier for healthcare providers with a recently lapsed license to } \\
\text { apply for a reinstatement with the Department of Safety and Professional Services (DSPS). } \\
\text { Out-of-state physicians can also practice telemedicine in Wisconsin with proper } \\
\text { notification of DSPS. } \\
\text { - [April } 5,2021 \text { Update] - EO } 105 \text { expired on April } 5,2021 \text {, meaning that Em. Order \#2 is no } \\
\text { longer in force and Wisconsin is no longer in a state of emergency. } \\
\text { - [1/11/22 Update] re: interstate telemedicine - WI medical license required. (WI Admin. Code } \\
\text { MED Ch. } 24.04 \text { ). }\end{array}$ & $\begin{array}{c}\text { Executive Order \#16 } \\
\frac{\text { Physician Notification }}{\frac{\text { Telemedicine }}{\text { of Healthcare }}} \\
\underline{\text { Provision }}\end{array}$ \\
\hline Wyoming & $\begin{array}{l}\text { - Wyoming offers broad credentialing privileges: "Physicians and physician assistants not } \\
\text { licensed in Wyoming may qualify to work here during the declared public health emergency } \\
\text { through the "consultation exemption." If approved to do so, the physician or physician } \\
\text { assistant is considered to be "consulting" with the State Health Officer. The exemption from } \\
\text { licensure, if approved, will be valid until the earlier of the end of the Public Health } \\
\text { Emergency or the termination by the State Health Officer of the physician's or physician } \\
\text { assistant's "consultation." Current, full and unrestricted licensure in at least one U.S. } \\
\text { jurisdiction or country is required. The exemption is not automatic, requires approval of the } \\
\text { Board of Medicine and the State Health Officer, and does not apply to all physicians and } \\
\text { physician assistants. } \\
\text { - A physician licensed in another state who has been approved for the "consultation } \\
\text { exemption" (See above) may initiate a physician-patient relationship with a new patient } \\
\text { under the exemption. } \\
\text { - The Wyoming Medical Board has an emergency temporary permit application on their } \\
\text { website for licensed out-of-state medical professionals seeking a temporary, voluntary } \\
\text { license. While there is no explicit mention of telemedicine, the WMB has a list of approved } \\
\text { - If you have an existing physician-patient relationship established in a face-to-face encounter } \\
\text { in your state, and the patient is not able to travel to your state now due to the Public Health } \\
\text { Emergency, you may continue that patient's care via telehealth, including telephone, without } \\
\text { a Wyoming physician license. This includes following up on procedures performed in your } \\
\text { home state, adjusting medication dosing, prescription refills, ordering diagnostic testing, etc. } \\
\text { The telehealth technology must allow you to meet the standard of care at all times. You may }\end{array}$ & $\frac{\text { Emergency Licensure }}{\text { Application }}$ \\
\hline
\end{tabular}


not, however, provide care that treats a new diagnosis or condition without a Wyoming physician license if you have not seen the patient for it in a face-to-face encounter in your home state. You also may not provide care beyond such a time as the standard of care dictates that a face-to-face encounter should occur.

- Status - Inactive, on February 28, 2022, Gov. Mark Gordon announced the public health emergency declaration will be rescinded on March 14, 2022. (Article).

Questions, comments, or corrections? Please contact Andrew Smith (asmith@fsmb.org) 